\title{
Growth, Yield, and Metabolic Responses of Temperature-stressed Tomato to Grafting onto Rootstocks Differing in Cold Tolerance
}

\author{
Georgia Ntatsi and Dimitrios Savvas \\ Agricultural University of Athens, Department of Crop Science, Laboratory of Vegetable Crops, Iera \\ Odos 75, 11855 Athens, Greece

\begin{abstract}
Georgia Ntatsi, Hans-Peter Kläring, and Dietmar Schwarz ${ }^{1}$
Leibniz Institute of Vegetable and Ornamental Crops (IGZ), Grossbeeren \& Erfurt e.V., Theodor

Echtermeyer Weg 1, D-14979 Großbeeren, Germany
\end{abstract}

\begin{abstract}
AdDitional INDEX words. antioxidants, ROS, scion, Solanum habrochaites, Solanum lycopersicum, suboptimal temperature
Abstract. Tomato (Solanum lycopersicum cv. Kommeet) plants were either self-grafted, grafted onto the coldsensitive cultivar Moneymaker or onto LA 1777, a cold-tolerant accession of Solanum habrochaites. Plants were grown at three different temperatures (T): optimal $\left(19.4^{\circ} \mathrm{C}\right)$, intermediate $\left(17^{\circ} \mathrm{C}\right)$, or low $\left(14.6^{\circ} \mathrm{C}\right)$. Grafting tomato 'Kommeet' onto LA 1777 increased shoot growth at intermediate and optimal $\mathrm{T}$ and root growth at low or intermediate $T$ in comparison with self-grafting or grafting onto 'Moneymaker'. Reducing $T$ significantly suppressed fruit yield as a result of reduced fruit number per plant without any interaction with grafting treatments. Grafting 'Kommeet' onto LA 1777 remarkably restricted fresh and dry fruit mass in comparison with self-grafting of 'Kommeet' as a result of a reduction in the fruit number per plant while not influencing flower number per plant and mean fruit mass, regardless of T regime. Negative effect of LA 1777 on fruit setting points to impairment of pollen fertility indicating signals originating from the root. At low and intermediate $T$, plants grafted onto LA 1777 were capable of increasing soluble carbohydrates, total amino acids, and guaiacol peroxidase activity in roots to higher levels than those grafted onto $S$. lycopersicum rootstocks while maintaining a significantly lower malondialdehyde content. These differences point to a much weaker oxidative stress in roots of plants grafted onto $S$. habrochaitis than those grafted onto $S$. lycopersicum rootstocks when exposed to low and intermediate T. Furthermore, plants grafted onto LA 1777 exhibited significantly higher levels of soluble carbohydrates, total amino acids, and guaiacol peroxidase activity in leaves and fruit and superoxide dismutase in fruit at low and intermediate T, which indicates that LA 1777 improved the level of antioxidant compounds in tomato shoots, thereby enhancing its adaptation to lower $T$ than optimal.
\end{abstract}

Tomato originates from subtropical regions. Its current economic optimum temperature $(\mathrm{T})$ for greenhouse cultivation and fruit set is at 19 to $20^{\circ} \mathrm{C}$ (Van der Ploeg and Heuvelink, 2005). Suboptimal $\mathrm{T}$ down to $10^{\circ} \mathrm{C}$ affects tomato growth and development by shortening internodes that reduce plant length, retard leaf expansion, reduce leaf number and total leaf fresh weight while increasing dry matter content and thickness of leaves arising from increased starch storage (Venema et al., 1999). When $\mathrm{T}$ falls below $12{ }^{\circ} \mathrm{C}$, growth is inhibited and will cause irreversible alteration and dysfunctions at the cellular level, depending on species, intensity, and duration of exposure (Kodama et al., 1995).

The most vulnerable stage in the growth cycle of higher plants is the reproductive phase (Nishiyama, 1995) and specifically during the formation of reproductive organs such as flowers, fruit, and seeds. The reproductive phase is affected by the interactions among plant morphology, physiology, and growth

Received for publication 5 Nov. 2013. Accepted for publication 7 Jan. 2014. This investigation was supported by the German Federal Ministry of Agriculture, Food, and Consumer Protection.

We appreciate the excellent technical assistance of Gundula Aust and Mandy Heinze (both IGZ) during the whole experimental procedure and thank Hans Spalholz (University of Arizona) for improving the language.

${ }^{1}$ Corresponding author. E-mail: schwarz@igzev.de. conditions (Van der Ploeg and Heuvelink, 2005). According to Van der Ploeg and Heuvelink (2005), optimal T for fruit set is between 18 and $20^{\circ} \mathrm{C}$. T below this level may lead to suppression of yield as a result of decreased fruit set owing to reduction in both quality and quantity of pollen (Domínguez et al., 2005) and retardation of truss appearance rates (Van der Ploeg and Heuvelink, 2005), which restricts fruit number per plant. Indeed, $\mathrm{T}$ below the optimal range will impair cell membrane fluidity and permeability, thereby resulting in ion leakage (Abbas, 2012), whereas intra- and extracellular water and nutrient movement are inhibited (Mahajan and Tuteja, 2005; Salinas, 2002), reactive oxygen species (ROS) are generated (Gill and Tuteja, 2010), photosynthesis may be restricted (Theocharis et al., 2012), and finally yield is reduced.

As a result of interaction of stress- and sugar-signaling pathways under abiotic stress conditions (Gupta and Knaur, 2005), plant metabolism is modulated. Indeed, during cold stress, sucrose accumulation in leaves leads to feedback inhibition of photosynthesis (Chiou and Bush, 1998; Ruelland et al., 2009). Thus, cellular components and structures are modified by suboptimal $\mathrm{T}$ exposure resulting in, for example, swelling of mitochondria and disruption in protein lipid accumulation and protein denaturation and stability (Kratsch and Wise, 2000; Siddiqui and Cavicchioli, 2006). Moreover, cellular dehydration caused by suboptimal $\mathrm{T}$ stress is attributed to reduced water 
uptake by roots (Yadav, 2010) and inhibition of stomatal closure (Wilkinson et al., 2001). Suboptimal T reduces not only water, but also nutrient uptake, thereby causing osmotic stress (Chinnusamy et al., 2007). In addition, suboptimal $\mathrm{T}$ causes peroxidation of unsaturated membrane lipids (Theocharis et al., 2012) thereby increasing membrane permeability to nutrients and ions that result in ion leakage (Gao et al., 2008). Such modifications are capable of disorganizing the entire plastid leading to growth reduction with an indirect yield loss. Furthermore, at suboptimal T, reactions of the Calvin cycle are down-regulated, and this may lead to overreduction of the photosynthetic light reactions and generation of ROS (Ensminger et al., 2006).

Reactive oxygen species are generated in plant cells even during a normal metabolic process such as photosynthesis and respiration (Apel and Hirt, 2004). Under optimal growth conditions, the damaging effect of ROS is prevented through the scavenging activity of antioxidants such as superoxide dismutase (SOD, EC 1.12.1.1) and guaiacol peroxidase (GPOD, EC 1.11.1.7) (Sundar et al., 2004). ROS scavenging capacity can be enhanced by hormones such as cytokinins (Zhou et al., 2007). However, when the balance between scavenging activity of antioxidants and ROS formation is disturbed as a result of suboptimal T stress, oxidative damage is caused.

Suboptimal $\mathrm{T}$ affects pollen quality and quantity (Domínguez et al., 2005), thereby reducing fruit set and concomitantly fruit number per plant. Long-term exposure to suboptimal T results in larger fruit (Van der Ploeg and Heuvelink, 2005).

To avoid yield losses resulting from suboptimal $\mathrm{T}$, indoor production of this economically important crop has become crucial. However, high-energy costs required for greenhouse heating, increasing energy prices, and environmental concerns about the emission of $\mathrm{CO}_{2}$ during the combustion of fossil fuel are forcing the greenhouse industry to improve its energy efficiency and to seek alternative approaches for enhancing plant tolerance (Ntatsi et al., 2013). An increase in tolerance might considerably reduce fuel cost (Venema et al., 2008). Already a reduction of $1{ }^{\circ} \mathrm{C}$ from the optimum $\mathrm{T}$ leads to a saving of $8 \%$ in energy costs (Elings et al., 2005). A possible strategy would be the introduction of new tolerant cultivars. Unfortunately, the very low genetic diversity of the existing cultivars (Venema et al., 2008) in combination with limitations in breeding methodology has led this approach to fail up to date.

Therefore, a promising tool to achieve this goal is grafting onto rootstocks that are known to affect canopy development, disease resistance, or cold-hardiness (Schwarz et al., 2010). The Solanaceae family includes many wild relatives of the cultivated tomato species $S$. lycopersicum with different degrees of tolerances to abiotic and biotic stresses. However, S. lycopersicum is characterized by low genotype diversity with respect to cold stress responses (Schwarz et al., 2010) and, therefore, the use of other Solanaceae species or of interspecific breeds as rootstocks might be an alternative. Accessions of $S$. habrochaites [synonym Lycopersicon hirsutum (Spooner et al., 2005)] are of particular interest as potential germplasm sources to widen the genetic variation in low $\mathrm{T}$ tolerance of the cultivated tomato (Venema et al., 2005, 2008). This wild tomato species originates from an altitude of $3200 \mathrm{~m}$ (Rick et al., 1994) where an adaptation to suboptimal T stress can be expected (Patterson et al., 1978). Superiority of $S$. habrochaites in terms of cold adaptability is attributed to adaptive mechanisms alleviating cell damage and retaining its reproduction ability under suboptimal $\mathrm{T}$ conditions (Venema et al., 2008).
Recent studies indicated that moderately suboptimal $\mathrm{T}$ has no adverse impact on root growth of high-altitude accessions of $S$. habrochaites (Venema et al., 2008). Therefore, a reduction in upward transport capacity of water and nutrients is not expected when this $S$. habrochaites accession line is exposed to suboptimal T (Venema et al., 2008). Similarly, imbalances in supply rate of root-deprived phytohormones to the scion caused by exposure to suboptimal $\mathrm{T}$ are also not expected. This hypothesis is further strengthened by findings indicating that use of rootstocks with a vigorous root system results in increased nutrient and water uptake, thereby enhancing the growth rate and yield performance of the whole plant (Lee, 1994).

In this article, the hypothesis is tested that using wild relatives of $S$. lycopersicum as rootstocks, characterized by a vigorous root system and tolerance to suboptimal T, may minimize yield losses in elite cultivars of grafted tomato when exposed to suboptimal T. The following genotypes were used as rootstocks: 1) the coldtolerant S. habrochaites accession LA 1777 (Venema et al., 2008); and 2) the elite cultivar Moneymaker, which appears to be cold-sensitive (Domínguez et al., 2005; Venema et al., 2008). The two rootstocks tested were grafted to the same commercial tomato cultivar Kommeet. Moreover, a control treatment with 3) self-grafted 'Kommeet' plants was applied to avoid confounding of effects imposed by grafting incision with those arising from the rootstock genotype. Impact of rootstock genotype on plant growth and yield under conditions of suboptimal (i.e., intermediate or low) $\mathrm{T}$ was assessed by measuring characteristics of shoot and root growth, fruit, yield, and fruit quality. To elucidate the physiological mechanisms underlying the observed effects on growth and yield, carbohydrate accumulation, carbon-to-nitrogen $(\mathrm{C} / \mathrm{N})$ ratio, oxidation characteristics, and antioxidant enzyme activities were also measured.

\section{Materials and Methods}

Plant material, growth conditions, and measurements. The experiment was carried out at the Leibniz Institute of Vegetable and Ornamental Crops, Großbeeren, Germany (lat. $52^{\circ} 20^{\prime} \mathrm{N}$, long. $13^{\circ} 18^{\prime} \mathrm{E}$, alt. $40 \mathrm{~m}$ ). A commercial tomato cultivar, Kommeet, was self-grafted or grafted onto the tomato cultivar Moneymaker or onto the line accession LA 1777 (S. habrochaites). Seeds of LA 1777 were sown in coarse sand on 20 June 2011; the two other cultivars were sown 1 week later. Grafting was performed 1 month later, when seedlings had developed three to four true leaves.

Grafted plants were transplanted on 11 Aug. 2011 into six $60-\mathrm{m}^{2}$ greenhouse cabins and cultivated at a heating set point of $18 / 16{ }^{\circ} \mathrm{C}$ (day/night). Roof ventilation was used once air $\mathrm{T}$ reached $27{ }^{\circ} \mathrm{C}$ for both day and night. At a relative humidity above $80 \%$, the vents were opened for exchange with outside air to reduce relative humidity. Pure $\mathrm{CO}_{2}$ was supplied to keep $\mathrm{CO}_{2}$ concentration in all cabins at ambient levels matching the outside environment.

Grafted plants were transferred into two troughs $(8 \times 0.2 \times$ $0.07 \mathrm{~m}$ ) located in the middle of the cabins where they were grown in a nutrient film technique. To manage the climate inside the cabin and to maintain appropriate growth, the two troughs were bordered from both sides by three further troughs. Each trough contained 12 plants. A standard nutrient solution (EC 3.7 $\mathrm{dS} \cdot \mathrm{m}^{-1}, \mathrm{pH}$ 5.6) for tomato was prepared by mixing stock solutions and rain water (De Kreij et al., 1997) and was supplied to the troughs every $10 \mathrm{~min}$ for $20 \mathrm{~s}$. The composition of the 
nutrient solution was measured periodically in the laboratory and corrected when necessary.

Once the second truss was flowering, on 9 Sept., set points for heating by day/night were shifted within 3 d to 20/18, 16/14, and $11 / 9{ }^{\circ} \mathrm{C}$ in each of the two greenhouse cabins. Different set points for heating in combination with global radiation and outside T resulted in mean cabin T during the treatments of 19.4 (optimal), 17 (intermediate), and $14.6^{\circ} \mathrm{C}$ (low).

Differences in the mean $\mathrm{T}$ resulted mainly from the differences during the night phase, whereas during the daytime and more specifically the middle of the day, $T$ differences between treatments were slight as a result of solar radiation and equal set points for ventilation. However, toward the end of the experiment, daytime solar radiation could not compensate for lower heating set points in the low $\mathrm{T}$ treatments resulting in mean average $\mathrm{T}$ in the low $\mathrm{T}$ treatment of only $11^{\circ} \mathrm{C}$. Treatments had minimum/maximum $\mathrm{T}$ as follows: optimal $\left(14.1 / 30.0{ }^{\circ} \mathrm{C}\right)$, intermediate $\left(12.7 / 30.7^{\circ} \mathrm{C}\right)$, and low $\left(9.2 / 30.1^{\circ} \mathrm{C}\right)$.

Mean daily photosynthetically active radiation $(P A R)$ at the canopy top decreased from $13.7 \mathrm{~mol} \cdot \mathrm{m}^{-2}$ during the first 4 weeks after planting to $2.5 \mathrm{~mol} \cdot \mathrm{m}^{-2}$ during the last 4 weeks of the experiment. Mean daily integral of $P A R$ over the entire treatment period was $7.4 \mathrm{~mol} \cdot \mathrm{m}^{-2} \cdot \mathrm{d}^{-1}$. The experiment was ended on 15 Dec. 2011.

GrowTH CHARACTERISTICS. Total number of flowers and fruit was counted at each truss beginning with Truss 3 until Truss 8 at four dates, 20,34,59, and $95 \mathrm{~d}$ after treatment start, to calculate a mean for the cultivation time. Leaf area was calculated as a mean of five fully expanded leaves. We measured the width of Leaves 11 to 15 counted from the shoot tip at the same dates as mentioned before (Schwarz and Kläring, 2001). At the end of the experiment, two plants of each grafted treatment were harvested per experimental unit, divided into stem, leaves, fruit, and roots. Subsequently, fresh weight of each of these plant parts was determined. Thereafter, all plant parts were dried separately at $70{ }^{\circ} \mathrm{C}$ to determine dry plant biomass and its allocation into different plant parts. Subsamples were used for later chemical analyses. Fresh root samples of $\approx 1$ $\mathrm{g}$ were collected from each experimental unit to measure root length (meters per gram) and mean root diameter (millimeters) using an image analyses system (WinRhizo; Regents Instruments, Sainte-Foy, Quebec, Canada). With these results and root fresh weight, total root surface area and total root length were estimated as described in Ntatsi et al. (2013).

YIELD. Harvesting started on 26 Oct. and finished 15 Dec. Number of harvested fruit and total fruit yield per plant were recorded up to the sixth truss. Marketable yield was classified as fruit without cracking, blossom-end rot (BER), blotchy ripening, deformations, and small fruit (diameter less than $30 \mathrm{~mm}$ ). Marketable fruit as well as fruit with BER were counted, fresh, and dry-weighed.

Tissue ANALyses. Powder from oven-dried root, leaf, and fruit samples were used to determine the total carbon and nitrogen content of different plant parts. The Dumas combustion technique was performed with the samples using a $\mathrm{C} / \mathrm{N}$ analyzer (Elementar, Hanau, Germany).

Soluble sugars were measured according to Geigenberger and Stitt (1993), starch according to Sonnewald (1992), and total amino acids according to Moore and Stein (1948) using a 96-position microplate spectrophotometer (Synergy HT; BioTek Instruments, Winooski, VT). Lipid peroxidation was estimated in leaves and roots by determining the concentration of thiobarbituric acid-reactive substances and quantified on its product, malondialdehyde (MDA), according to the method described by He et al. (2009) and Hodges et al. (1999). MDA was not detected in fruit and therefore data are presented only for roots.

For enzyme analysis, $0.1 \mathrm{~g}$ of each pulverized frozen sample (leaf, root, or fruit) was homogenized with ice-cold $25 \mathrm{~mm}$ HEPES buffer ( $\mathrm{pH} 7.8$ ) including $0.2 \mathrm{~mm}$ EDTA, $2 \mathrm{~mm}$ ascorbate, and $2 \%(\mathrm{w} / \mathrm{v})$ polyvinylpyrrolidone. The homogenate was centrifuged at $4{ }^{\circ} \mathrm{C}$ and $17,562 g_{\mathrm{n}}$ for $5 \mathrm{~min}$. Supernatants were used for enzyme analysis. All steps in preparation of enzyme extract were carried out at $4{ }^{\circ} \mathrm{C}$. Protein concentration was determined as described by Bradford (1976) with bovine serum albumin as the standard. GPOD activity was determined according to Cakmak and Marshner (1992) as modified by Egley et al. (1983). Increase in absorbance at $510 \mathrm{~nm}$ caused by guaiacol oxidation $\left(E=26.6 \mathrm{mM} \cdot \mathrm{cm}^{-1}\right)$ was measured over $50 \mathrm{~min}$. Glutathione reductase (GR) activity was assayed according to Rao et al. (1996) with some modifications. Briefly, the reaction mixture in a total volume of $200 \mu \mathrm{L}$ consisted of $25 \mathrm{~mm}$ potassium buffer ( $\mathrm{pH} 7.0$ ), $0.1 \mathrm{~mm}$ EDTA, $0.5 \mathrm{~mm}$ oxidized glutathione, $0.12 \mathrm{~mm}$ NADPH, and $10 \mu \mathrm{L}$ plant sample. GR activity was measured by following the decrease in absorbance of oxidized glutathione at $340 \mathrm{~nm}(E=6.2$ $\left.\mathrm{mM}^{-1} \cdot \mathrm{cm}^{-1}\right)$. SOD activity was determined according to the method of Rao and Sresty (2000). One unit of enzyme activity was defined as the amount of enzyme required to impose a $50 \%$ inhibition in the rate of nitro blue tetrazolium reduction measured at $560 \mathrm{~nm}$.

STATISTICAL ANALYSIS. Three T treatments were combined with three grafting combinations in a two-factorial design with two replications per $\mathrm{T}$ and five per grafting combination in each $\mathrm{T}$ replication. Data were subjected to a two-factorial analysis of variance. Factor effects were evaluated using Fisher's F-test. When $\mathrm{T}$ or grafting combination had a significant impact but the interaction between them was not significant, the means between the three $\mathrm{T}$ levels tested and the three grafting combinations, respectively, were separated using Duncan's multiple range test at a significance level of $P \leq 0.05$. The same test was used to separate means of all nine treatments when the interaction was found to be significant. Statistical analyses were carried out using the STATISTICA software package Version 9.0 (StatSoft, Tulsa, OK).

\section{Results}

VEgETATIVE GROWTH AND ROOT MORPHOLOGY. Root fresh (Fig. 1A) and dry mass (Fig. 1B) of plants grafted onto LA 1777 were significantly larger than self-grafted 'Kommeet' plants at both low $\left(14.6{ }^{\circ} \mathrm{C}\right)$ and intermediate $\mathrm{T}\left(17^{\circ} \mathrm{C}\right)$. However, at optimum $\mathrm{T}\left(19.4{ }^{\circ} \mathrm{C}\right)$ and in self-grafted 'Kommeet', they remained the same, and thus no significant difference was found between them. Plants grafted onto 'Moneymaker' exhibited consistently lower root fresh and dry mass than those grafted onto the other two rootstocks at all T levels. Total root area (Fig. 1C) and total root length (Fig. 1D) were larger for self-grafted plants and those grafted onto LA 1777 than for plants grafted onto 'Moneymaker' at 14.6 and $17^{\circ} \mathrm{C}$. At $19.4^{\circ} \mathrm{C}$, the total root area of plants grafted onto LA 1777 was similar to those found in plants grafted onto 'Moneymaker'.

Grafting 'Kommeet' onto the $S$. habrochaites accession LA 1777 increased fresh leaf mass (Fig. 1E), dry leaf mass (Fig. $1 \mathrm{~F}$ ), and total leaf area (Fig. 1G) at optimal or intermediate $\mathrm{T}$ in 
Rootstock:

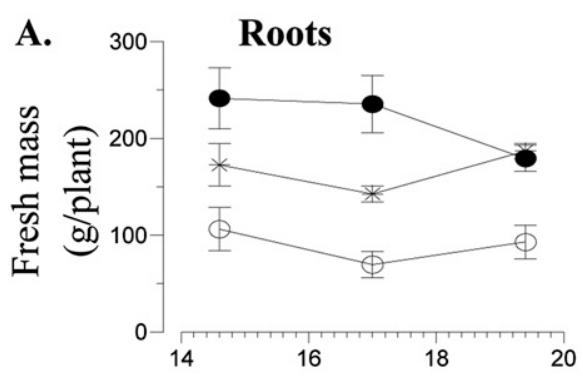

B.

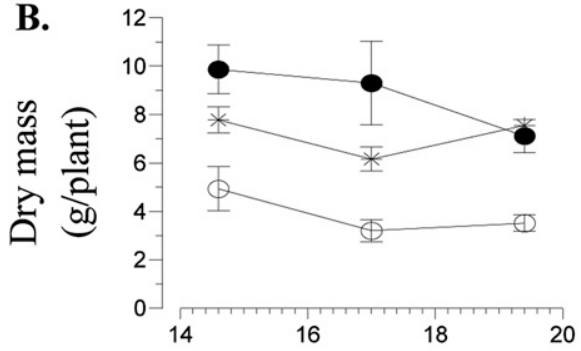

C.
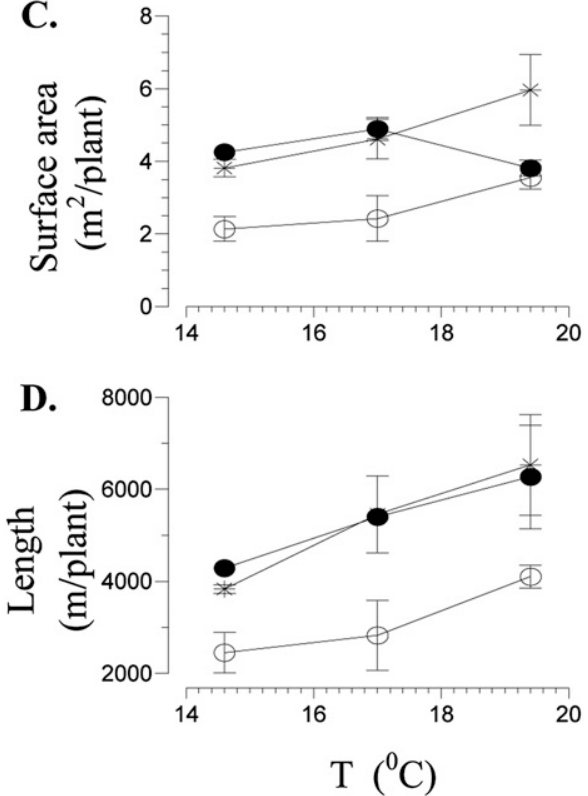

LA
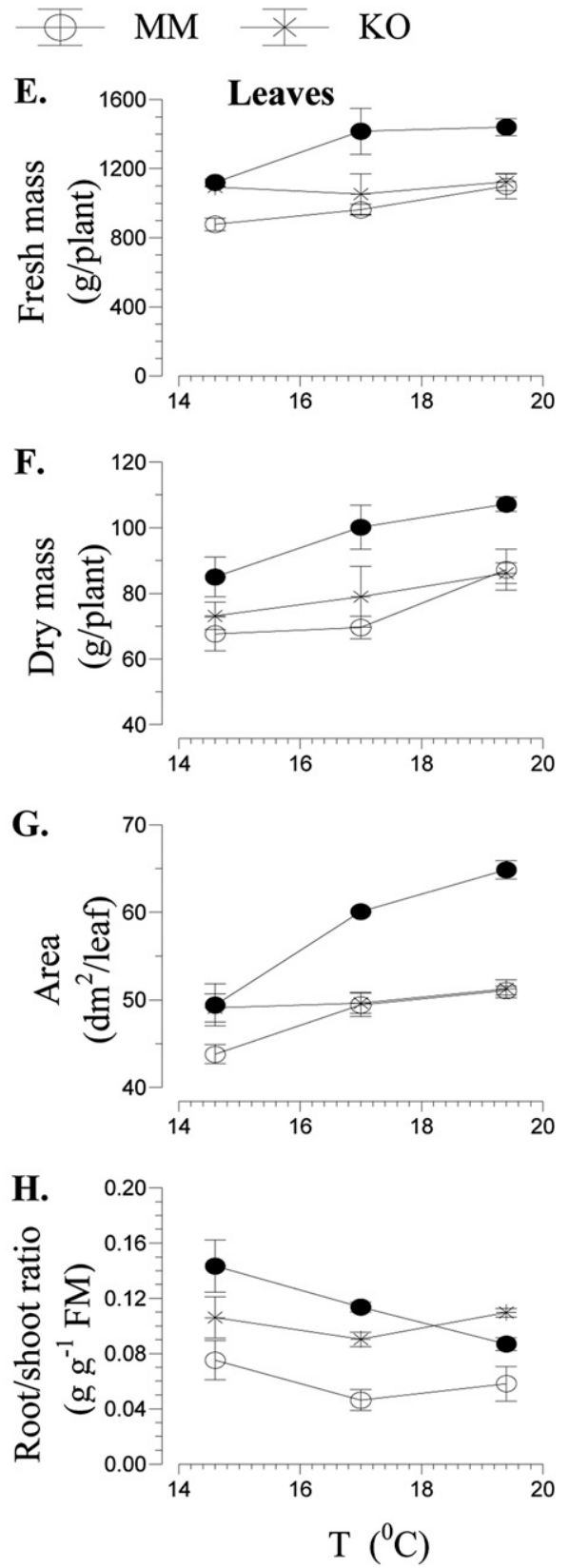

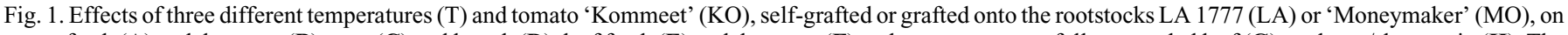
root fresh (A) and dry mass $(\mathbf{B})$, area $(\mathbf{C})$ and length $(\mathbf{D})$, leaf fresh $(\mathbf{E})$ and dry mass $(\mathbf{F})$ and mean area per a fully expanded leaf $(\mathbf{G})$, and root/shoot ratio $(\mathbf{H})$. The values are means \pm SES of 10 replications.

comparison with self-grafted 'Kommeet' or grafting onto the cold-sensitive tomato 'Moneymaker'. However, at low T, fresh and dry leaf mass and total leaf area of plants grafted onto LA 1777 decreased to similar levels with those measured in self-grafted 'Kommeet'. Nevertheless, fresh and dry leaf mass and total leaf area measured in 'Kommeet' grafted onto 'Moneymaker' were also reduced at $14.6{ }^{\circ} \mathrm{C}$, and thus they remained at significantly lower levels than in plants grafted onto LA 1777. Depending on differences reported previously and their extent at 14.6 and $17^{\circ} \mathrm{C}$, root/shoot ratio (Fig. 1H) was significantly higher in 'Kommeet' grafted onto LA 1777 than in the other two treatments. However, at $19.4^{\circ} \mathrm{C}$, the self-grafted 'Kommeet' exhibited a significantly higher root/shoot ratio than those grafted onto LA 1777.
Yield ChaRaCTERISTiCs. Total fresh and dry mass of fruit per plant and marketable fruit fresh weight were strongly reduced when plants were exposed to low $\mathrm{T}$ in comparison with intermediate or optimal $\mathrm{T}$ regardless of grafting treatment (Table 1). A decrease in $\mathrm{T}$ from 19.4 to $17^{\circ} \mathrm{C}$ reduced only fresh and marketable fruit mass but had no significant impact on fruit dry mass. In contrast, average fresh weight of a tomato fruit was enhanced by reduction of T from 19.4 to 17 or $14.6^{\circ} \mathrm{C}$ regardless of grafting treatment. Remarkably, intermediate $\mathrm{T}$ reduced appreciably fresh fruit mass affected by BER, whereas at $14.6^{\circ} \mathrm{C}$, no fruit with BER was recorded. No interaction was observed between $\mathrm{T}$ and rootstock genotype.

Total and marketable yield of 'Kommeet' grafted onto LA 1777 was significantly lower than that obtained from self-grafted 
Table 1. Effects of three different temperatures (T) and tomato scion (S) 'Kommeet' (KO) self-grafted or grafted onto the rootstocks (R) LA 1777 (LA) or 'Moneymaker' (MM) on fruit fresh, dry, average and marketable mass, and fruit with blossom-end rot (BER). ${ }^{\mathrm{z}}$

\begin{tabular}{|c|c|c|c|c|c|c|}
\hline & & & & Mass & & \\
\hline Tres & & $\begin{array}{l}\text { Fresh } \\
\text { (g/plant) }\end{array}$ & $\begin{array}{c}\text { Dry } \\
\text { (g/plant) }\end{array}$ & $\begin{array}{c}\text { Avg } \\
\text { (g/fruit) }\end{array}$ & $\begin{array}{c}\text { Marketable } \\
\text { (g/plant) }\end{array}$ & $\begin{array}{c}\text { BER } \\
\text { (g/plant) }\end{array}$ \\
\hline$\overline{\mathrm{T}}$ & Low & $819 \mathrm{c}$ & $25.80 \mathrm{~b}$ & $172 \mathrm{a}$ & $807 \mathrm{c}$ & $0.00 \mathrm{~b}$ \\
\hline & Optimal & $3261 \mathrm{a}$ & $93.08 \mathrm{a}$ & $104 \mathrm{c}$ & $2974 \mathrm{a}$ & $103.08 \mathrm{a}$ \\
\hline $\mathrm{R} / \mathrm{S}$ & $\mathrm{LA} / \mathrm{KO}$ & $1891 \mathrm{~b}$ & $62.61 \mathrm{~b}$ & 140 & $1806 \mathrm{~b}$ & $8.07 \mathrm{~b}$ \\
\hline & $\mathrm{KO} / \mathrm{KO}$ & $2619 \mathrm{a}$ & $87.60 \mathrm{a}$ & 137 & $2467 \mathrm{a}$ & $55.24 \mathrm{a}$ \\
\hline & Statistical sig & & & & & \\
\hline $\mathrm{T}$ & & $* * *$ & $* * *$ & $* * *$ & $* * *$ & $* *$ \\
\hline $\mathrm{R} / \mathrm{S}$ combination & & $*$ & $*$ & NS & $*$ & $*$ \\
\hline $\mathrm{T} \times \mathrm{R} / \mathrm{S}$ interaction & & NS & NS & NS & NS & NS \\
\hline
\end{tabular}

'Kommeet' (Table 1). Yield of plants grafted onto 'Moneymaker' was lower than that of self-grafted 'Kommeet' and higher than that of plants grafted onto LA 1777 but the differences were not significant. However, fruit dry mass of plants grafted onto 'Moneymaker' was significantly lower than that measured in self-grafted 'Kommeet'. Plants grafted onto LA 1777 produced significantly fewer fruit with BER in comparison with those grafted onto 'Moneymaker' or were self-grafted. Rootstock genotype had no impact on average fruit mass.

Decrease in $\mathrm{T}$ reduced fruit number and fruit/flower ratio regardless of grafting combination but had no significant impact on flower number (Table 2). Grafting had also no impact on flower number. However, the rootstocks LA 1777 and 'Moneymaker' significantly reduced fruit number of 'Kommeet' compared with self-grafted. The fruit/flower ratio recorded in plants grafted onto LA 1777 was significantly lower compared with that for plants grafted onto 'Moneymaker' and self-grafted resulting from reduced fruit setting.

TOTAL C, N, PROTEIN, AND CARBOHYDRATE CONCENTRATION IN ROoTs. In roots, 'Kommeet' grafted onto LA 1777 exhibited significantly lower total $\mathrm{N}$ concentrations (Fig. 2A) at low and intermediate $\mathrm{T}$ and significantly higher total $\mathrm{C}$ concentrations (Fig. 2B) at intermediate and optimal $\mathrm{T}$ in comparison with the other two grafting treatments. At optimal $\mathrm{T}$, total $\mathrm{N}$ in roots of LA 1777 was significantly lower only in comparison with 'Moneymaker'-grafted plants. Decrease of T from 19.4 to 17 and $14.6{ }^{\circ} \mathrm{C}$ increased total $\mathrm{N}$ level in roots of 'Kommeet' or 'Moneymaker' but had no impact on that measured in LA 1777. In contrast, $\mathrm{T}$ decrease from 19.4 to $14.6{ }^{\circ} \mathrm{C}$ increased total $\mathrm{C}$ concentration in roots of LA 1777 while not influencing total $\mathrm{C}$ in the other two rootstocks. Root $\mathrm{C} / \mathrm{N}$ ratio (Fig. 2C) decreased with descending $\mathrm{T}$ in all grafting treatments, whereas the highest $\mathrm{C} / \mathrm{N}$ ratio in roots was measured in LA 1777 at all T. Reduction of T from 19.4 to $14.6{ }^{\circ} \mathrm{C}$ in the greenhouse environment reduced total protein content in roots (Fig. 2D) regardless of rootstock genotype without any significant differences between grafting treatments. Exposure of tomato plants to $14.6{ }^{\circ} \mathrm{C}$ increased glucose, fructose, and sucrose concentration of roots (Fig. 2E-G) when compared with 17 and $19.4^{\circ} \mathrm{C}$ but had no impact on starch (Fig. 2H). Root glucose concentrations were unaffected by the
Table 2. Effects of three different temperatures (T) and tomato scion (S) 'Kommeet' (KO), self-grafted or grafted onto the rootstocks (R) LA 1777 (LA) or 'Moneymaker' (MM) on fruit and flower number and fruit/flower ratio (FR/FL). ${ }^{2}$

\begin{tabular}{llrcr}
\hline & & $\begin{array}{c}\text { Fruit } \\
\text { Treatment }\end{array}$ & $\begin{array}{c}\text { Flowers } \\
\text { (no./plant) }\end{array}$ & $\begin{array}{c}\mathrm{FR} / \mathrm{FL} \\
(\text { no./no. }\end{array}$ \\
\hline $\mathrm{T}$ & Low & $8.40 \mathrm{c}$ & 50.21 & $0.17 \mathrm{c}$ \\
& Intermediate & $15.44 \mathrm{~b}$ & 54.00 & $0.29 \mathrm{~b}$ \\
& Optimal & $19.46 \mathrm{a}$ & 52.89 & $0.36 \mathrm{a}$ \\
& & & & \\
$\mathrm{R} / \mathrm{S}$ & $\mathrm{LA} / \mathrm{KO}$ & $10.13 \mathrm{~b}$ & 52.71 & $0.19 \mathrm{c}$ \\
& $\mathrm{MM} / \mathrm{KO}$ & $13.83 \mathrm{~b}$ & 50.67 & $0.27 \mathrm{~b}$ \\
& $\mathrm{KO} / \mathrm{KO}$ & $19.34 \mathrm{a}$ & 53.73 & $0.36 \mathrm{a}$
\end{tabular}

$\begin{array}{lccc}\quad \text { Statistical significance } & & & \\ \mathrm{T} & * * & \mathrm{NS} & * * \\ \mathrm{R} / \mathrm{S} \text { combination } & * & \mathrm{NS} & * \\ \mathrm{~T} \times \mathrm{R} / \mathrm{S} \text { interaction } & \mathrm{NS} & \mathrm{NS} & \mathrm{NS}\end{array}$

${ }^{\mathrm{z}}$ Different letters within the same column indicate significant differences between the means according to Duncan's multiple range test $(P \leq 0.05)$. NS, *,** and *** indicate nonsignificant or significant differences at $P \leq$ $0.05, P \leq 0.01$, and $P \leq 0.001$, respectively.

rootstock. However, fructose, sucrose, and starch levels in roots of LA 1777 were significantly higher at $14.6^{\circ} \mathrm{C}$ than those measured in 'Kommeet' or 'Moneymaker'. Furthermore, at $17{ }^{\circ} \mathrm{C}$, also starch levels were significantly higher in roots of LA 1777 than in the other two rootstocks.

TOTAL C, N, PROTEIN, AND CARBOHYDRATE CONCENTRATION IN LEAVES. Decrease of T to $14.6^{\circ} \mathrm{C}$ in the greenhouse environment reduced total $\mathrm{N}$ in leaves regardless of the rootstock genotype (Fig. 3A). However, reduction was considerably stronger in plants grafted onto LA 1777 and 'Moneymaker' than in selfgrafted 'Kommeet'. Leaf C concentration increased strongly as $\mathrm{T}$ decreased from 19.4 to $17^{\circ} \mathrm{C}$ but dropped to similar levels as in self-grafted 'Kommeet' at $14.6{ }^{\circ} \mathrm{C}$ (Fig. 3B). Leaf C concentration in plants grafted onto 'Moneymaker' was significantly lower than in the other two grafting treatments at all $\mathrm{T}$ levels. As a result of the reported variations in leaf $\mathrm{C}$ and $\mathrm{N}$, leaf $\mathrm{C} / \mathrm{N}$ ratio increased as $\mathrm{T}$ decreased, whereas the highest $\mathrm{C} / \mathrm{N}$ leaf values were found 

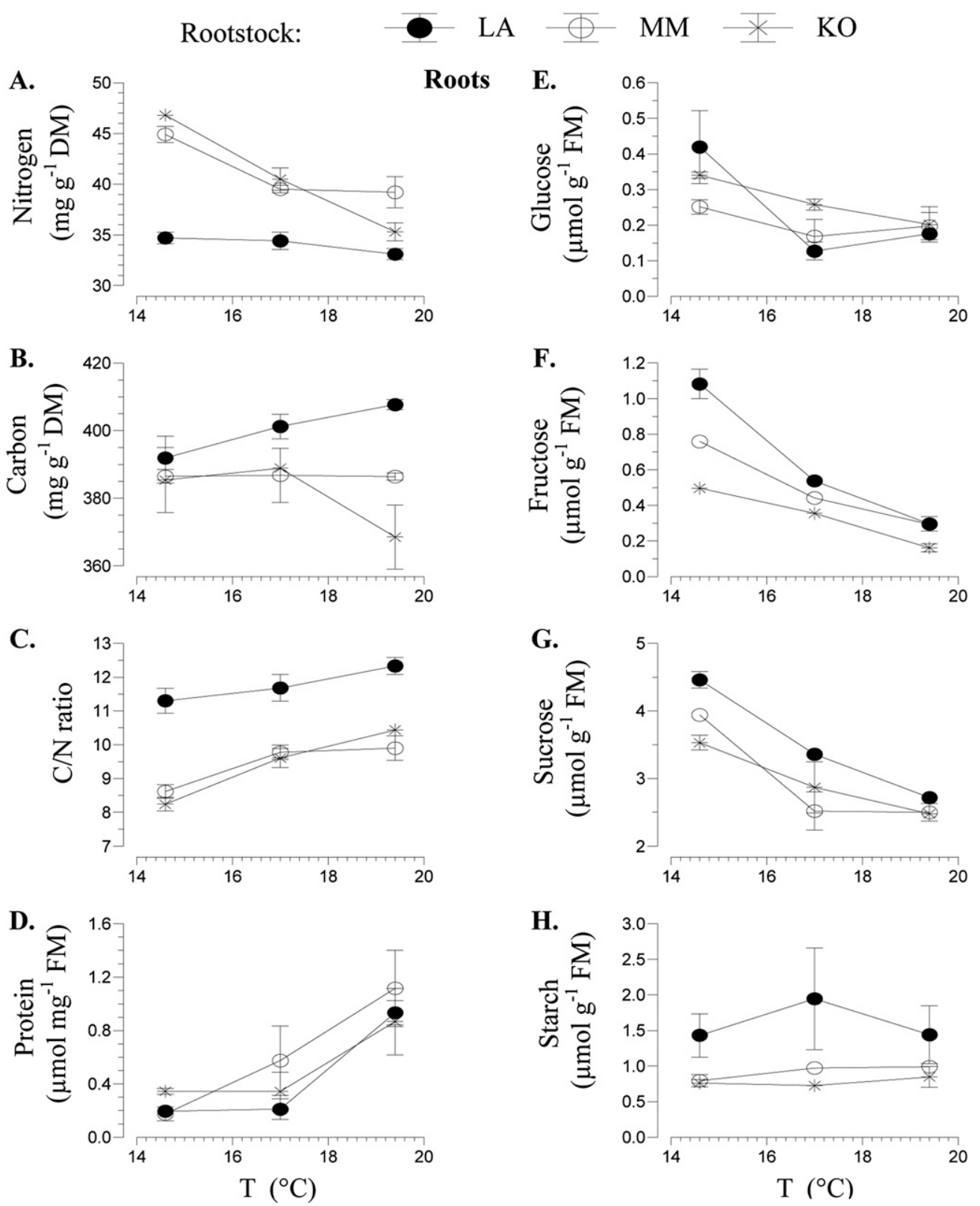

Fig. 2. Effects of three different temperatures (T) and tomato 'Kommeet' (KO), self-grafted or grafted onto the rootstocks LA 1777 (LA) or 'Moneymaker' (MO), on total nitrogen $(\mathrm{N})(\mathbf{A})$, total carbon $(\mathrm{C})(\mathbf{B})$ and carbon/nitrogen ratio $(\mathrm{C} / \mathrm{N})(\mathbf{C})$, total protein $(\mathbf{D})$, glucose $(\mathbf{E})$, fructose $(\mathbf{F})$, sucrose $(\mathbf{G})$, and starch concentration (H) of roots. The values are means \pm SES of 10 replications.

in plants grafted onto LA 1777 (Fig. 3C). Total proteins in leaves were restricted as $\mathrm{T}$ decreased without any significant difference between grafting treatments (Fig. 3D).

Exposure of tomato plants to $14.6{ }^{\circ} \mathrm{C}$ increased glucose, fructose, sucrose, and starch concentration of leaves when compared with 17 and $19.4{ }^{\circ} \mathrm{C}$ (Fig. 3E-H). At suboptimal T, leaf glucose, fructose, and sucrose concentrations were significantly higher in 'Kommeet' grafted onto LA 1777 than in self-grafted and plants grafted onto 'Moneymaker', other than fructose at $17{ }^{\circ} \mathrm{C}$ with no difference between the grafting treatments. Grafting onto LA 1777 reduced starch concentration in plant leaves growing at $14.6{ }^{\circ} \mathrm{C}$. Furthermore, at $14.6^{\circ} \mathrm{C}$, fructose and sucrose concentration in leaves of plants grafted onto 'Moneymaker' was significantly higher than in selfgrafted plants.
TOTAL C, N, PROTEIN, AND CARBOHYDRATE CONCENTRATION IN FRUIT. Total N in fruit of plants grafted onto 'Moneymaker' was low at 19.4 and $17{ }^{\circ} \mathrm{C}$ but increased appreciably at $14.6{ }^{\circ} \mathrm{C}$, thereby reaching greater total $\mathrm{N}$ levels than the other two grafted treatments (Fig. 4A). Total $\mathrm{C}$ in fruit decreased as $\mathrm{T}$ was reduced from 19.4 to $14.6{ }^{\circ} \mathrm{C}$ without significant differences between grafting treatments (Fig. 4B). Reduction of $\mathrm{T}$ decreased $\mathrm{C} / \mathrm{N}$ ratio in fruit of plants grafted onto 'Moneymaker' but had no impact on $\mathrm{C} / \mathrm{N}$ ratio in fruit of self-grafted or plants grafted onto LA 1777 (Fig. 4C). The latter exhibited significantly lower fruit $\mathrm{C} / \mathrm{N}$ ratios at 17 and $19.4^{\circ} \mathrm{C}$ than self-grafted 'Kommeet' or plants grafted onto 'Moneymaker'. When T was reduced from 19.4 to $14.6^{\circ} \mathrm{C}$, total protein concentration increased in tomato fruit from plants grafted onto 'Moneymaker' and self-grafted 'Kommeet', whereas in the latter, an increase was observed also at $17{ }^{\circ} \mathrm{C}$ 


\section{Rootstock: $\quad$ LA $\frac{\emptyset}{\square}$ MM $\frac{\mp}{\mp}$ KO}
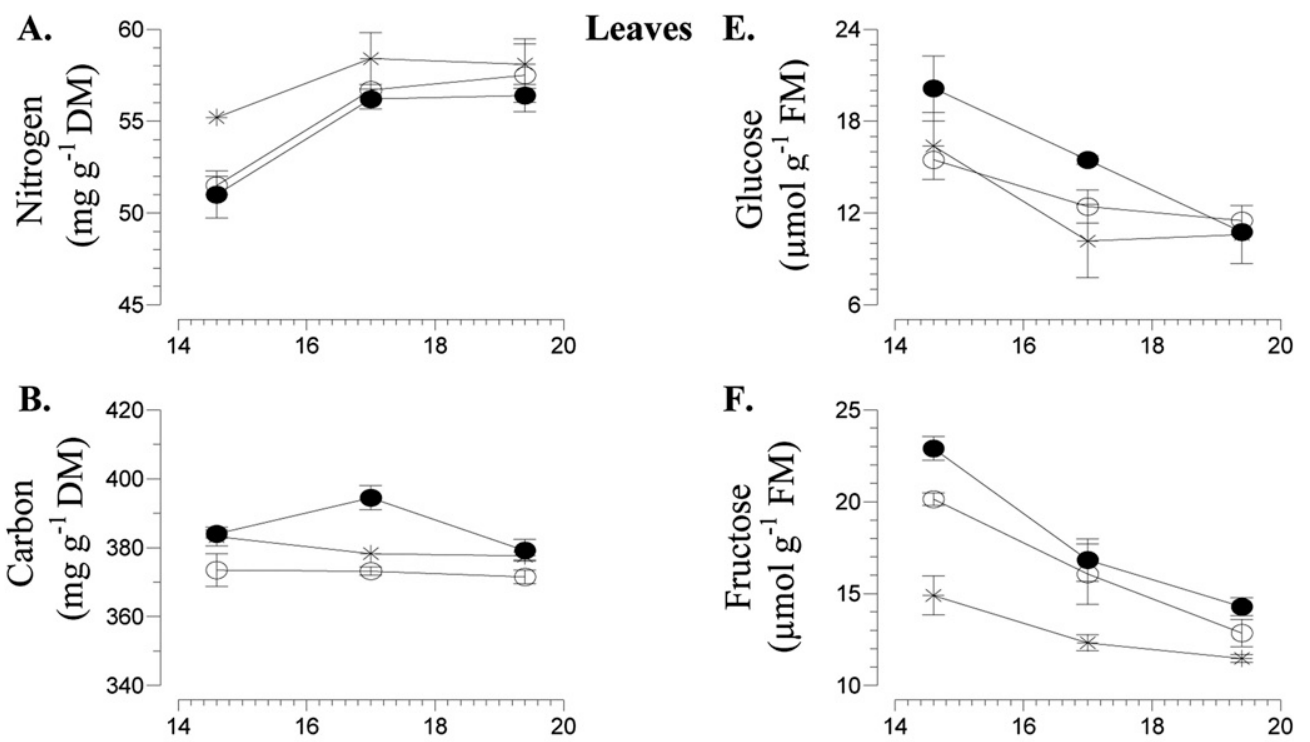

C.

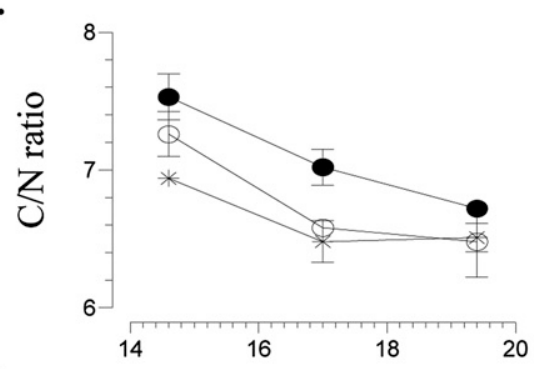

G.
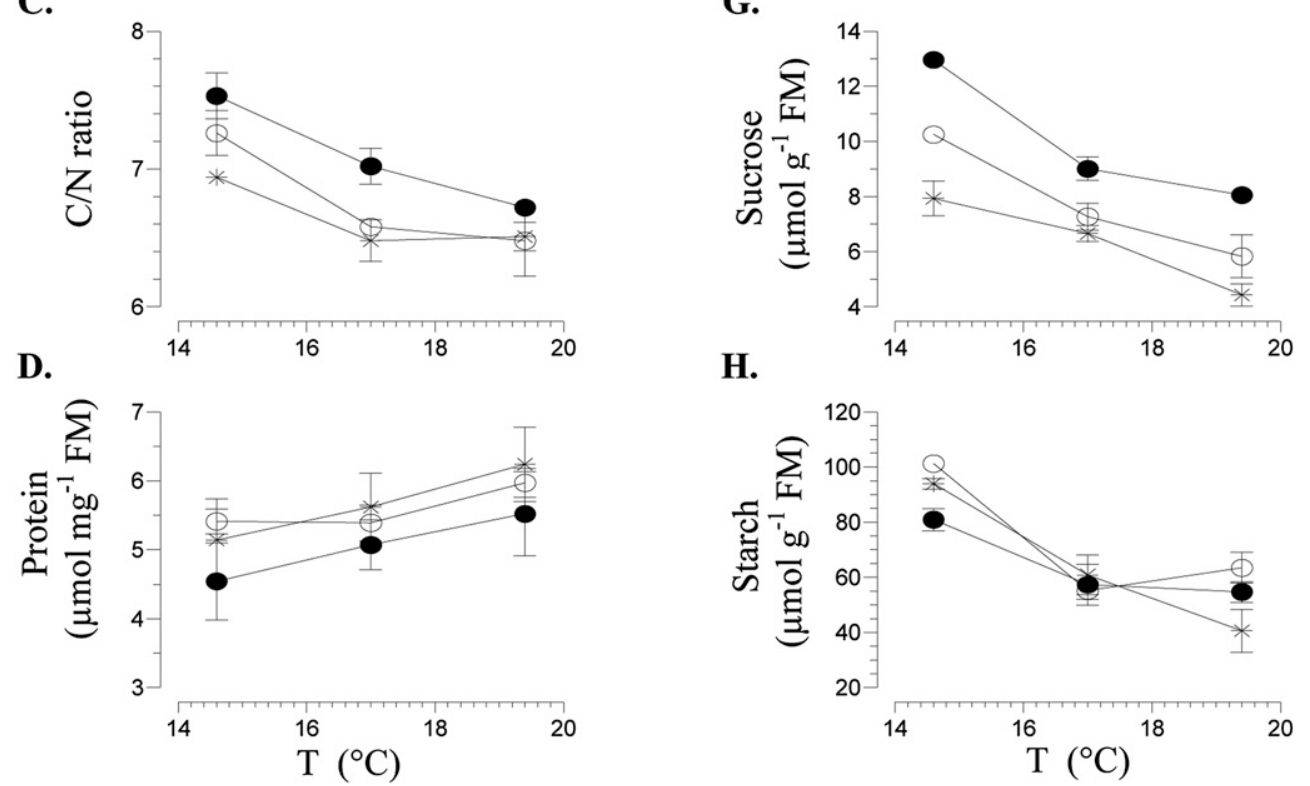

Fig. 3. Effects of three different temperatures (T) and tomato 'Kommeet' (KO), self-grafted or grafted onto the rootstocks LA 1777 (LA) or 'Moneymaker' (MO), on total nitrogen $(\mathrm{N})(\mathbf{A})$, total carbon $(\mathrm{C})(\mathbf{B})$ and carbon/nitrogen ratio $(\mathrm{C} / \mathrm{N})(\mathbf{C})$, total protein $(\mathbf{D})$, glucose $(\mathbf{E})$, fructose $(\mathbf{F})$, sucrose $(\mathbf{G})$, and starch concentration (H) of leaves. The values are means \pm SEs of 10 replications.

(Fig. 4D). In contrast, fruit protein concentration was not influenced by $\mathrm{T}$ in plants grafted onto LA 1777. At optimal T, self-grafted 'Kommeet' exhibited the lowest fruit protein concentration in comparison with the other grafting treatments but this difference was reversed at intermediate T. Concentrations of glucose, fructose, and sucrose in fruit significantly increased with decreasing $\mathrm{T}$ in all grafting treatments (Fig. 4E-G). Fruit glucose, fructose, and sucrose concentrations in plants grafted onto LA 1777 were significantly higher than in the other two grafting treatments at all $\mathrm{T}$ levels, except fructose at intermediate and optimal $\mathrm{T}$, which was similar in the other grafting treatment. At optimal T, plants grafted onto 'Moneymaker' exhibited lower fruit starch levels than self-grafted 'Kommeet' and plants grafted onto 'Moneymaker' (Fig. 4H). When T was reduced from 19.4 to
$17{ }^{\circ} \mathrm{C}$, fruit starch concentration increased to similar levels in all grafting treatments. However, at $14.6{ }^{\circ} \mathrm{C}$, starch concentration decreased to lower levels than at $17^{\circ} \mathrm{C}$ in fruit of self-grafted or plants grafted onto 'Moneymaker'.

OXIDATION ChaRACTERISTICS, TOTAL AMINO ACIDS, AND ANTIOXIDANT ENZYME ACTIVITIES. Decreasing T increased root MDA concentration when 'Kommeet' was either self-grafted or grafted onto 'Moneymaker' but had no significant impact when plants were grafted onto LA 1777 (Fig. 5A). As a result, at suboptimal T, root MDA was significantly lower in plants grafted onto LA 1777 than in self-grafted plants or those grafted onto 'Moneymaker'. In contrast, MDA concentration in leaves was not influenced either by $\mathrm{T}$ or by the rootstock genotype (data not shown). GR activity in roots and leaves was not influenced 

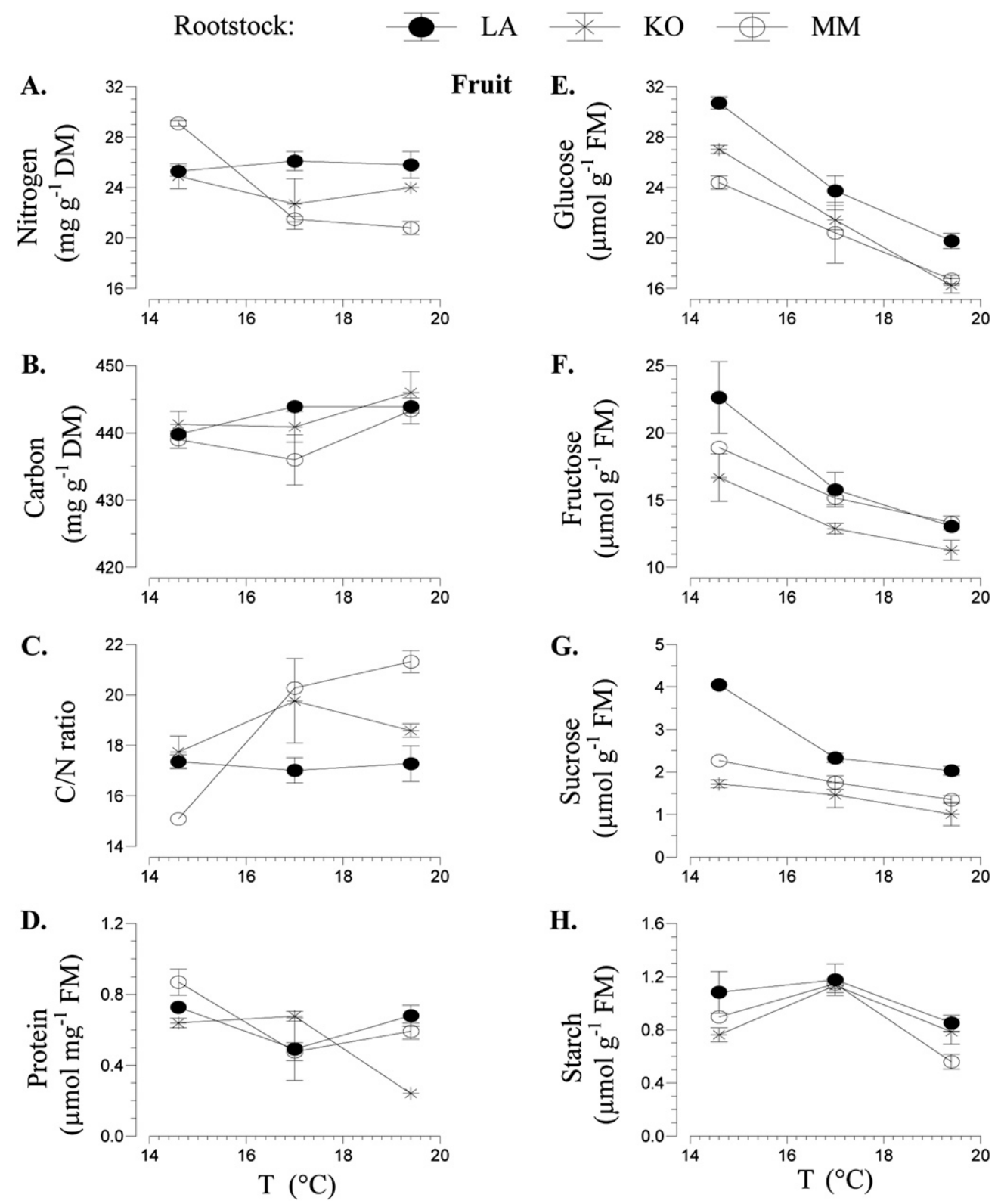

Fig. 4. Effects of three different temperatures (T) and tomato 'Kommeet' (KO), self-grafted or grafted onto the rootstocks LA 1777 (LA) or 'Moneymaker' (MO), on total nitrogen $(\mathrm{N})(\mathbf{A})$, total carbon $(\mathrm{C})(\mathbf{B})$ and carbon/nitrogen ratio $(\mathrm{C} / \mathrm{N})(\mathbf{C})$, total protein $(\mathbf{D})$, glucose $(\mathbf{E})$, fructose $(\mathbf{F})$, sucrose $(\mathbf{G})$, and starch concentration (H) of fruit. The values are means \pm SES of 10 replications.

by T or rootstock genotype (data not shown). In fruit, GR activity at $19.4{ }^{\circ} \mathrm{C}$ was significantly lower in plants grafted onto 'Moneymaker' than in the other two grafting treatments, whereas it was not influenced by $\mathrm{T}$ decrease from 19.4 to $17^{\circ} \mathrm{C}$ (Fig. 5B). However, at $14.6^{\circ} \mathrm{C}$, GR activity in fruit increased in all grafting treatments, the increase being significantly higher in plants grafted onto LA 1777.

Total amino acid concentration in the roots tended to increase with decreasing $\mathrm{T}$ (Fig. 5C). The increase was significantly stronger in plants grafted onto LA 1777 than in self-grafted plants and those grafted onto 'Moneymaker'. At intermediate T, total amino acid concentration in roots of plants grafted onto 'Moneymaker' was significantly lower than in those of selfgrafted 'Kommeet'. Total amino acid concentration in leaves was not influenced either by $\mathrm{T}$ or by the rootstock genotype (data not shown). Fruit total amino acid concentration increased in all grafting treatments with decreasing $\mathrm{T}$, the increase being more profound as $\mathrm{T}$ was reduced from 17 to $14.6{ }^{\circ} \mathrm{C}$ (Fig. 5D). At intermediate and optimal $\mathrm{T}$, lowest total amino acid concentration in fruit was measured in self-grafted 'Kommeet', whereas at $14.6{ }^{\circ} \mathrm{C}$, fruit total amino acid concentration was significantly higher in plants grafted onto LA 1777 than in those grafted onto S. lycopersicum rootstocks.

Superoxide dismutase activity in roots of plants grafted onto LA 1777 was similar at all T levels (Fig. 6A). However, SOD activity in roots decreased as $\mathrm{T}$ was reduced from 19.4 to $17^{\circ} \mathrm{C}$ in self-grafted 'Kommeet' and from 19.4 to $14.6^{\circ} \mathrm{C}$ in plants grafted onto 'Moneymaker'. At optimal T, self-grafted 'Kommeet' had the greatest SOD root activity, whereas at intermediate T, plants grafted onto LA 1777 had the greatest SOD root activity. At the 

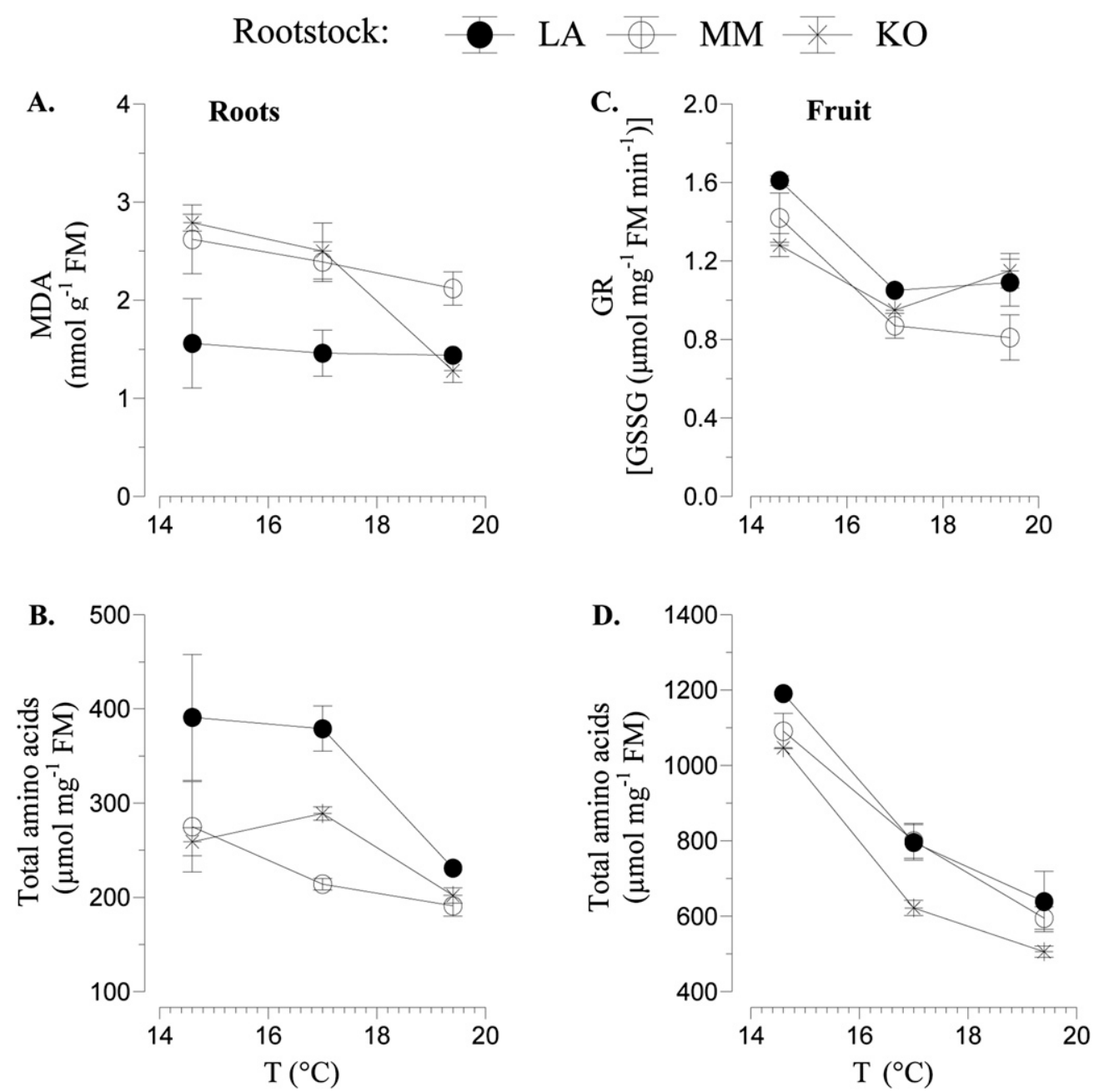

Fig. 5. Effects of three different temperatures (T) and tomato 'Kommeet' (KO), self-grafted or grafted onto the rootstocks LA 1777 (LA) or 'Moneymaker' (MO), on malondialdehyde (MDA) concentration (A) and total amino acids (B) of roots and glutathione reductase (GR) activity (C), and total amino acids (D) of fruit. The values are means \pm SES of 10 replications. GSSG $=$ oxidized glutathione.

low T, no significant differences were found between these two treatments. SOD activity was significantly greater in leaves of self-grafted 'Kommeet' than in those of the other grafting treatments at 19.4 and $17^{\circ} \mathrm{C}$ (Fig. 6B). However, at $14.6{ }^{\circ} \mathrm{C}$, leaf SOD activity was similar in all grafting treatments. SOD activity in fruit was not influenced by $\mathrm{T}$ decrease from 19.4 to $17{ }^{\circ} \mathrm{C}$ and by grafting treatment at $19.4{ }^{\circ} \mathrm{C}$ but was significantly reduced by grafting onto 'Moneymaker' at $17{ }^{\circ} \mathrm{C}$ (Fig. 6C). At $14.6^{\circ} \mathrm{C}$, fruit SOD activity increased in plants grafted onto LA 1777 , whereas it was not influenced by $\mathrm{T}$ in the other two grafting treatments. In self-grafted and plants grafted onto LA 1777, GPOD activity was raised by low $\mathrm{T}$ in comparison with intermediate or optimal $\mathrm{T}$, the increase being more profound with the LA 1777 root genotype (Fig. 6D). In contrast, T had no impact on root GPOD activity in plants grafted onto 'Moneymaker'. Low T reduced GPOD activity in leaves of 'Kommeet' grafted onto $S$. lycopersicum rootstocks, but not in those grafted onto LA 1777 which exhibited the highest GPOD levels at low T (Fig. 6E). Lowest GPOD activity at $19.4{ }^{\circ} \mathrm{C}$ was measured in fruit from plants grafted onto LA 1777 . However, at $17{ }^{\circ} \mathrm{C}$, fruit GPOD activity increased in plants grafted onto LA 1777 to similar levels as in plants grafted onto 'Moneymaker', whereas the values measured in self-grafted 'Kommeet' were significantly lower than in the other two grafting treatments (Fig. 6F). The further $\mathrm{T}$ decrease from 17 to $14.6^{\circ} \mathrm{C}$ diminished GPOD activity in fruit from self-grafted plants and those grafted onto 'Moneymaker' but increased fruit GPOD activity in plants grafted onto LA 1777.

\section{Discussion}

In contrast to a previous report (Bloom et al., 2004), but in accordance with later results (Venema et al., 2008), LA 1777, an accession of $S$. habrochaites, proved to be a compatible rootstock for cultivated tomato (S. lycopersicum). Moreover, in this present study, the growing period after grafting lasted 21 weeks, including a 9-week harvesting period, longer than the 5-week harvest period used in the study of Venema et al. (2008). Thus, the present study is the first report on long-term compatibility of LA 1777 used as a rootstock for cultivated tomato.

As indicated by our data shown in Figure $1 \mathrm{~A}-\mathrm{D}$, vegetative shoot growth of 'Kommeet' is unaffected by intermediate $\mathrm{T}$ $\left(17^{\circ} \mathrm{C}\right)$, whereas it was affected by long-term exposure to low $\mathrm{T}\left(14.6^{\circ} \mathrm{C}\right)$ depending on rootstock genotype. Mild reductions of vegetative shoot growth of 'Kommeet' at low T, when used as a scion in grafted tomato, are in contrast to those previously 
Rootstock: $\quad$ LA $\underline{\varnothing}$ MM $\frac{\mp}{\mp} \mathrm{KO}$
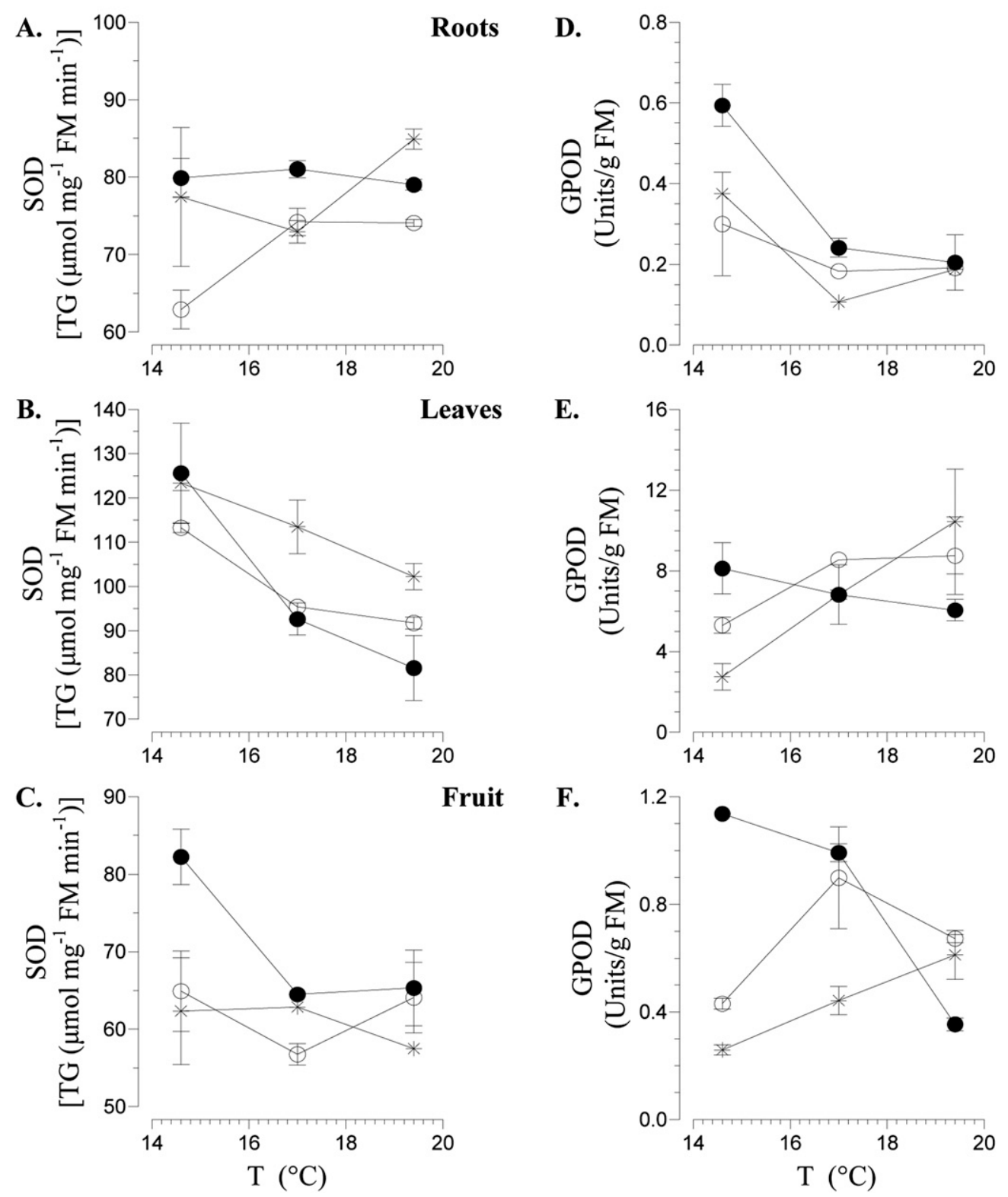

Fruit

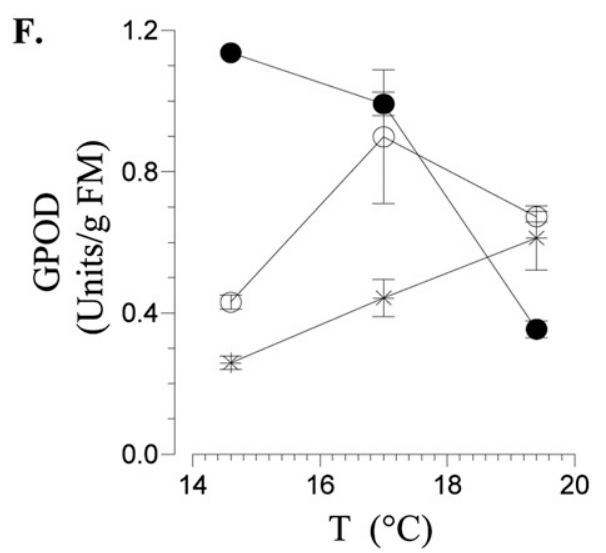

Fig. 6. Effects of three different temperatures (T) and tomato 'Kommeet' (KO), self-grafted or grafted onto the rootstocks LA 1777 (LA) or 'Moneymaker' (MO), on superoxide dismutase (SOD) (A-C) and guaiacol peroxidase (GPOD) activity (D-F) of roots (A, D), leaves $(\mathbf{B}, \mathbf{E})$, and fruit $(\mathbf{C}, \mathbf{F})$. The values are means \pm SES of 20 replications. $\mathrm{TG}=$ triglycerides.

reported. Venema et al. (2008) found strong reduction after a 2-week exposure of tomato grafted onto 'Moneymaker', self-grafted or grafted onto LA 1777 , at $15^{\circ} \mathrm{C}$ compared with $25{ }^{\circ} \mathrm{C}$. One explanation for this difference in responses of tomato to low $\mathrm{T}$ is the genotype of the scion. It seems that 'Kommeet' as a scion is much more tolerant to suboptimal T than 'Moneymaker', which is considered cold-sensitive (Domínguez et al., 2005; Fernández-Muñoz et al., 1995). Genotypic differences in responses of tomato shoot growth to suboptimal T have been reported also by Paul et al. (1984). An additional and evident reason for the contrasting difference in responses of grafted tomato to $14.6{ }^{\circ} \mathrm{C}$ between our experiment and that of Venema et al. (2008) is the duration of exposure. It seems that short-term low $\mathrm{T}$ stress severely impairs vegetative growth of tomato, but in the long term, growth can partly recover as a result of physiological adaptation to stress conditions (Goulas et al., 2006).

Shortening of root length at low $\mathrm{T}$, regardless of rootstock genotype, indicates that low $\mathrm{T}$ imposes formation of thicker roots in tomato, also reported by Kasper and Bland (1992). Nevertheless, our knowledge about key physiological mechanisms underlying the inhibitory effect of suboptimal root-zone $\mathrm{T}$ on the cell cycle and cell elongation in roots is currently insufficient (Walter et al., 2009). Rootstock genotype has a strong impact on root growth when the same cultivar is used as a scion, as indicated by a root biomass reduction of $50 \%$ when 'Moneymaker' was compared with LA 1777 or self-grafted even at optimal T. Optimal T causes stress on LA 1777 resulting in 
reduced root mass. LA 1777 is a cold-tolerant accession adopted to $\mathrm{T}$ below the optimal treatment. Used as a rootstock, it responds at optimum $\mathrm{T}$ with a growth reduction also shown in previous investigations (Venema et al., 2008).

However, the most interesting finding of this study regarding vegetative tomato growth is that 'Kommeet' grafted onto LA 1777 exhibited improved shoot growth at intermediate and optimal $\mathrm{T}$ and root growth at low or intermediate $\mathrm{T}$ in comparison with self-grafted or plants grafted onto 'Moneymaker'. These findings, in combination with the fact that suboptimal $\mathrm{T}$ did not restrict root length, while enhancing total root area in 'Kommeet' grafted onto LA 1777, indicate that this graft combination provides clear advantages in terms of vegetative tomato growth. Uptake of some nutrients and water is strongly affected by reducing root $\mathrm{T}$ in non-grafted $S$. lycopersicum but not in S. habrochaites (Bloom et al., 1998, 2004). Change in root morphology may be interpreted as adaptation of nutrient acquisition mechanisms to low $\mathrm{T}$, aimed at extending the absorbing surface area per unit root mass or length (Macduff et al., 1986). Thus, formation of a more extensive root system by tomato plants grafted onto LA 1777 as T is reduced, and the concurrent increase in root/shoot ratio, provides an additional advantage to these plants when exposed to suboptimal $\mathrm{T}$ in terms of nutrient and water uptake. An increase in root/shoot ratio has been interpreted by Equiza et al. (2001) as an adaptation aimed at overcoming restrictions in water absorption, which, in case of low $\mathrm{T}$, might be related to increased water viscosity and root resistance to water transport.

Reductions in fruit yield when tomato is exposed to suboptimal $\mathrm{T}$ have been already reported by several investigators (Aroca et al., 2001; Korkmaz and Dufault, 2002; Van der Ploeg and Heuvelink, 2005). Suppression of yield at suboptimal T in our study originates from decreased fruit set owing to reduction in pollen quantity, quality (Domínguez et al., 2005), and retardation of truss appearance rates (Van der Ploeg and Heuvelink, 2005), which restricts fruit number per plant. Our findings support this hypothesis because suboptimal $\mathrm{T}$ decreased total fruit yield by reducing total fruit number, whereas average yield rose. Increase of the average fresh fruit mass as $\mathrm{T}$ was lowered indicates that low $\mathrm{T}$ impairs more severely the formation and fecundity of pollen than the availability of assimilates after fruit setting, as also suggested by Adams et al. (2001) and Schwarz et al. (2010).

Another interesting finding of the present study is that reducing ambient $T$ restricts the calcium-related physiological disorder BER in fruit. According to Kiegle et al. (2000), low T increases cytosolic $\mathrm{Ca}^{2+}$, whereas according to Knight et al. (1996) and Tahtiharju et al. (1997), $\mathrm{Ca}^{2+}$ could play an essential role in the cold acclimation process. As reported by Ho and White (2005), cytosolic $\mathrm{Ca}^{2+}$ coordinates cell expansion by influencing the incorporation of vesicles containing enzymes required for membrane and wall construction into the plasma membrane. Therefore, an increase in fruit calcium resulting from suboptimal T may prevent morphological defects such as membrane permeability that may result in abnormal leakage of solutes from cells and cell death and concurrently the occurrence of BER. Significant restriction of BER in fruit by grafting onto LA 1777 points to a relationship of $\mathrm{Ca}^{2+}$ transport to fruit. Further research is needed to elucidate the mechanisms underlying this relationship.

Grafting 'Kommeet' onto LA 1777 significantly restricted total fruit yield in comparison with grafting onto 'Moneymaker' and self-grafting as a result of a strong reduction of fruit numbers per plant at $27 \%$ and $48 \%$, respectively. Because the flower number per plant was similar in all grafting treatments, it is concluded that use of LA 1777 as a rootstock impairs pollen fertility. Pollen produced by $S$. habrochaites is more coldtolerant than that of $S$. lycopersicum (Domínguez et al., 2005). However, according to the same authors, S. lycopersicum $\times S$. habrochaites crosses and subsequently segregating generations with $S$. lycopersicum show reduced pollen fertility as a result of interspecific hybrid sterility. The present study indicates that the combination of $S$. habrochaites and S. lycopersicum impairs pollen fertility not only if these related species are crossed, but also if the latter is grafted onto the former. These findings point to a role of plant hormones originating from roots and transported to shoot either on pollen viability or on any other function related to pollination and fruit setting (Garay-Arroyo et al., 2012; Sirova et al., 2011). Thus, in terms of yield performance, use of $\mathrm{S}$. habrochaites as a rootstock may pose similar difficulties with those faced when using this wild tomato species for breeding of elite cultivars; i.e., reduced pollen fertility. Further research is needed to confirm this hypothesis.

Previous research has indicated that exposure of tomato to low $\mathrm{T}$ suppresses carbon export from leaves, thereby imposing accumulation of soluble carbohydrates in these plant organs (Rosa et al., 2009a; Strand et al., 2003). Restriction of sugar export from leaves of cold-stressed plants originates mainly from reduced sink activity resulting from exposure of roots, fruit, and stem apices to low T (Rosa et al., 2009b). Reduced C use in sink organs stressed by low $\mathrm{T}$ slows down the rate of sugar unloading, thereby imposing feedback retardation of sugar-loading in leaf phloem (Ainsworth and Bush, 2011). As a result, soluble carbohydrates may accumulate in both photosynthetically active leaves and sink organs such as roots and fruit, as was the case in the present study. Nevertheless, accumulation of soluble sugars in plant tissues stressed by low T may also serve as an adaptive mechanism to stress conditions. Plant metabolism is modulated under abiotic stress conditions and accumulated sugars may act as osmolytes or substrates for cellular respiration (Gupta and Knaur, 2005) or as antioxidative agents (Bogdanovic et al., 2008) that scavenge ROS (Noctor and Foyer, 1998). Thus, a stronger accumulation of soluble sugars in plant tissues exposed to suboptimal $\mathrm{T}$ may indicate a higher adaptability to cold-stress conditions. In agreement with this consideration, in our study, soluble carbohydrate levels in roots of plants grafted onto the cold-tolerant rootstock LA 1777 were higher than in roots of the other grafting combinations under low $\mathrm{T}$.

Higher soluble sugar levels in leaves and fruit of plants grafted onto LA 1777 compared with those self-grafted or grafted onto 'Moneymaker' at $14.6{ }^{\circ} \mathrm{C}$ may predominantly reflect the stronger reduction of leaf biomass in the former compared with the latter two treatments when T dropped (Fig. 1A-D). However, higher soluble sugar levels at $17^{\circ} \mathrm{C}$ in leaves and fruit of plants grafted onto LA 1777 compared with the other two grafting treatments were not accompanied by significant reductions in shoot biomass. Thus, it is reasonable to assume that at $17^{\circ} \mathrm{C}$ increased levels of glucose and fructose in leaves and fruit of plants grafted onto LA 1777 compared with those from the other two grafting treatments served mainly as an adaptive mechanism to suboptimal $\mathrm{T}$, which is triggered by roots. This consideration is in agreement with previous findings (Cook et al., 2004; Ma et al., 2009; Zhang et al., 2007) indicating that plants subjected to suboptimal $\mathrm{T}$ stress use 
sugars and amino acids as protective compounds. Protection of leaf growth and photosynthesis through hormonal signals originating from cucumber roots under cold stress conditions such as abscisic acid has been reported by Zhou et al. (2007). A link between signaling pathways of abscisic acid and sugar metabolism has been reported by several investigators in Arabidopsis thaliana (Arenas-Huertero et al., 2000; Cheng et al., 2002; Rook et al., 2001).

Striking differences in root $\mathrm{N}$ and $\mathrm{C}$ between 'Kommeet' grafted onto LA 1777 and plants either self-grafted or onto 'Moneymaker' reflect presumably anatomical differences related to allocation of plant biomass into polysaccharides deposited in cell walls and cytosol. Reduced root and leaf protein as $\mathrm{T}$ decreased was obviously related to substantial increases of total amino acid concentration in roots and fruit. As reported by Mitchell and Madore (1992) and Zhang et al. (2007), plants subjected to suboptimal $\mathrm{T}$ use amino acids, in addition to sugars, as protective compounds. Accumulation of amino acids in plant tissues exposed to suboptimal $\mathrm{T}$ originates mainly from upregulation of nitrate reductase activity (Tucker and Ort, 2002). Thus, it seems that the stronger increase of total amino acid concentration in roots of plants grafted onto LA 1777 and plants either self-grafted or onto 'Moneymaker' reflects the higher tolerance of LA 1777 to suboptimal T. Nevertheless, the ability of LA 1777 to increase total amino acid concentration when exposed to suboptimal $\mathrm{T}$ does not seem to be governed by root/ shoot signaling compounds. Indeed, grafting of 'Kommeet' onto LA 1777 did not result in a stronger increase of total amino acids in leaves and fruit in comparison with self-grafting or grafting onto 'Moneymaker'.

Malondialdehyde is one of several low-molecular-mass end products arising from decomposition of various primary and secondary lipid peroxidation compounds (Demiral and Türkan, 2005). Therefore, an increased MDA level in plant tissue is considered a definite index of oxidative stress resulting in increased formation of ROS. The contrasting differences in root MDA levels between 'Kommeet' plants grafted onto LA 1777 and those grafted onto $S$. lycopersicum rootstocks when exposed to 17 and $14.6^{\circ} \mathrm{C}$ clearly demonstrate superiority of the former in avoiding oxidative stress caused by suboptimal T. Nevertheless, use of a cold-tolerant rootstock did not reduce the oxidative stress in leaves of tomato when plants were exposed to suboptimal T, as indicated by the similar leaf MDA levels in all grafting treatments at 17 and $14.6{ }^{\circ} \mathrm{C}$. Plants are capable of deploying various enzymatic defense systems to minimize deleterious effects of ROS, which include the enzymes GR, GPOD, and SOD (Gill and Tuteja, 2010; Tuteja, 2009). As reported by Foyer and Noctor (2005), antioxidant capacity increases during cold acclimation in several plants as an adaptive mechanism to low $\mathrm{T}$, especially in those characterized by enhanced tolerance to suboptimal or low T. Results of the present study indicate a weak involvement of GPOD, SOD, and GR in defense mechanisms against oxidative stress caused by low $\mathrm{T}$ when tomato is grafted onto $S$. lycopersicum rootstocks, which restricted roots, leaves, and fruit, respectively. However, plants grafted onto LA 1777 were capable of raising appreciably GPOD activity in roots and fruit and SOD activity in leaves and fruit when exposed to low $\mathrm{T}$, thereby increasing their capacity to scavenge ROS caused by low $\mathrm{T}$ stress. These results indicate that the activities of some antioxidant enzymes in leaves and fruit of tomato are influenced not only by the shoot, but also by the root genotype. Similar results have also been reported by Liu et al. (2012) and Zhang et al.
(2010). Further research is needed to elucidate the underlying signaling pathways that contribute to protection of leaves and fruit from oxidative stress that are governed by root genotype.

\section{Conclusion}

Grafting tomato 'Kommeet' onto the cold-tolerant accession LA 1777 of the wild relative of tomato $S$. habrochaites increases root biomass at low $\left(14.6^{\circ} \mathrm{C}\right)$ and intermediate $\mathrm{T}\left(17^{\circ} \mathrm{C}\right)$, both referring to suboptimal $\mathrm{T}$, and the leaf biomass at intermediate and optimum $\mathrm{T}\left(19.4^{\circ} \mathrm{C}\right)$ in comparison with self-grafting and grafting onto the cold-sensitive 'Moneymaker'. However, grafting onto LA 1777 significantly restricts yield as a result of significant suppression of fruit number per plant in comparison with grafting onto 'Moneymaker' and self-grafting while not influencing flower number per plant, which points to a root-induced restriction of fruit set. These results indicate that $S$. habrochaites impairs pollen fertility not only when used to breed interspecific hybrids with $S$. lycopersicum, but also when used as rootstock.

Increase of soluble carbohydrates, total amino acids, and GPOD activity in the roots of plants grafted onto LA 1777 and low MDA concentration at suboptimal T point to a much weaker cold-induced oxidative stress in roots of these plants. Furthermore, plants grafted onto LA 1777 exhibited significantly higher levels of soluble carbohydrates, total amino acids, and GPOD activity in leaves and fruit and superoxide dismutase in fruit at $14.6^{\circ} \mathrm{C}$. These results indicate that LA 1777 is capable of improving levels of some antioxidant compounds in tomato shoots, thereby improving its adaptation to $14.6{ }^{\circ} \mathrm{C}$.

Taken together, results of the present study indicate that use of cold-tolerant accessions of $S$. habrochaites as tomato rootstocks can enhance tolerance of grafted plants to suboptimal $\mathrm{T}$ by improving their capacity to scavenge ROS. However, protection conferred by $S$. habrochaites against cold-induced oxidative stress may not be beneficial in terms of yield under suboptimal $\mathrm{T}$ conditions because this wild tomato relative may impair pollen fertility even when used as a tomato rootstock. Future research using microarray analysis of accessions of $S$. habrochaites as rootstocks in a series of rootstock/scion combinations might elucidate genes controlling root/shoot signaling that influence pollen fertility. Acquired knowledge could be used to establish biomarkers to screen not only wild tomato genotypes serving as rootstocks, but also to test rootstock/scion combinations potentially tolerant to suboptimal $\mathrm{T}$.

\section{Literature Cited}

Abbas, S.M. 2012. Effects of low temperature and selenium application on growth and the physiological changes in sorghum seedlings. J. Stress Physiol. Biochem. 8:268-286.

Adams, S.R., K.E. Cockshull, and C.R.J. Cave. 2001. Effect of temperature on the growth and development of tomato fruits. Ann. Bot. (Lond.) 88:869-877.

Ainsworth, E.A. and D.R. Bush. 2011. Carbohydrate export from the leaf: A highly regulated process and target to enhance photosynthesis and productivity. Plant Physiol. 155:64-69.

Apel, K. and H. Hirt. 2004. Reactive oxygen species: Metabolism, oxidative stress and signal transduction. Annu. Rev. Plant Biol. 55:373-399.

Arenas-Huertero, F., A. Arroyo, L. Zhou, J. Sheen, and P. Leon. 2000. Analysis of arabidopsis glucose insensitive mutants, gin5 and gin6, reveals a central role of the plant hormone $\mathrm{ABA}$ in the regulation of plant vegetative development by sugar. Genes Dev. 14:2085-2096. 
Aroca, R., F. Tognoni, J.J. Irigoyen, M. Sánchez-Díaz, and A. Pardossi 2001. Different root low temperature response of two maize genotypes differing in their chilling sensitivity. Plant Physiol. Biochem. 39:1067-1073.

Bloom, A.J., L.B. Randall, P.A. Meyerhof, and D.A. St. Clair. 1998. The chilling sensitivity of root ammonium influx in a cultivated and wild tomato. Plant Cell Environ. 21:191-199.

Bloom, A.J., M.A. Zwieniecki, J.B. Passioura, L.B. Randall, N.M. Holbrook, and D.A. St. Clair. 2004. Water relations under root chilling in a sensitive and a tolerant tomato species. Plant Cell Environ. 27:971-979.

Bogdanovic, J., M. Mojovic, N. Milosavic, A. Mitrovic, Z. Vucinic, and I. Spasojevic. 2008. Role of fructose in the adaptation of plants to cold induced oxidative stress. Eur. Biophys. J. 37:1241-1246.

Bradford, M. 1976. A rapid and sensitive method for the quantitation of microgram quantities of protein utilizing the principle of protein-dye binding. Anal. Biochem. 72:248-254.

Cakmak, I. and H. Marshner. 1992. Magnesium deficiency and high light intensity enhance activities of superoxide dismutase, ascorbate peroxidase, and glutathione reductase in bean leaves. Plant Physiol. 98:1222-1227.

Cheng, W.H., A. Endo, L. Zhou, J. Penney, H.C. Chen, A. Arroyo, P. Leon, E. Nambara, T. Asami, M. Seo, T. Koshiba, and J. Sheen. 2002. A unique short-chain dehydrogenase/reductase in arabidopsis abscisic acid biosynthesis and glucose signaling. Plant Cell 14:27232743.

Chinnusamy, V., J. Zhu, and J.K. Zhu. 2007. Cold stress regulation of gene expression in plants. Trends Plant Sci. 12:444-451.

Chiou, T.J. and D.R. Bush. 1998. Sucrose is a signal molecule in assimilate partitioning. Proc. Natl. Acad. Sci. USA 95:4784-4788.

Cook, D., S. Fowler, O. Fiehn, and M.F. Thomashow. 2004. A prominent role for the $\mathrm{CBF}$ cold response pathway in configuring the low-temperature metabolome of arabidopsis. Proc. Natl. Acad. Sci. USA 101:15243-15248.

De Kreij, C., W. Voogt, A.L. Van den Bos, and R. Baas. 1997. Voedingsoplossingen voor de teelt van tomaat in gesloten teeltsystemen. Brochure VG 2 Tomaat, Proefstation voor Bloemisterij en Glasgroente, Naaldwijk, The Netherlands.

Demiral, T. and I. Türkan. 2005. Comparative lipid peroxidation, antioxidant defense systems and proline content in roots of two rice cultivars differing in salt tolerance. Environ. Exp. Bot. 53:247-257.

Domínguez, E., J. Cuartero, and R. Fernandez-Munoz. 2005. Breeding tomato for pollen tolerance to low temperatures by gametophytic selection. Euphytica 142:253-263.

Egley, G.H., R.N. Paul, K.C. Vaughn, and S.O. Duke. 1983. Role of peroxidase in the development of water impermeable seed coats in Sida spinosa L. Planta 157:224-232.

Elings, A., F.L.K. Kempkes, R.C. Kaarsemaker, M.N.A. Ruijs, N.J. Van de Braak, and T.A. Dueck. 2005. The energy balance and energy-saving measures in greenhouse tomato cultivation. Acta Hort. 691:67-74.

Ensminger, I., N. Busch, and N.P.A. Huner. 2006. Photostasis and cold acclimation: Sensing low temperature through photosynthesis. Physiol. Plant. 126:28-44.

Equiza, M.A., J.P. Mirave, and J.A. Tognetti. 2001. Morphological, anatomical and physiological responses related to differential shoot vs. root growth inhibition at low temperature in spring and winter wheat. Ann. Bot. (Lond.) 87:67-76.

Fernández-Muñoz, R., J.J. González-Fernández, and J. Cuartero. 1995. Genetics of the viability of pollen grain produced at low temperatures in Lycopersicon Mill. Euphytica 84:139-144.

Foyer, C.H. and G. Noctor. 2005. Redox homeostasis and antioxidant signaling: A metabolic interface between stress perception and physiological responses. Plant Cell 17:1866-1875.

Gao, C., D. Xing, L. Li, and L. Zhang. 2008. Implication of reactive oxygen species and mitochondrial dysfunction in the early stages of plant programmed cell death induced by ultraviolet-C overexposure. Planta 227:755-767.
Garay-Arroyo, A., M. De La Paz Sánchez, B. García-Ponce, E. Azpeitia, and E.R. Álvarez-Buylla. 2012. Hormone symphony during root growth and development. Dev. Dyn. 241:1867-1885.

Geigenberger, P. and M. Stitt. 1993. Sucrose synthase catalyses a readily reversible reaction in vivo in developing potato tubers and other plant tissues. Planta 189:329-339.

Gill, S.S. and N. Tuteja. 2010. Polyamines and abiotic stress tolerance in plants. Plant Signal. Behav. 5:26-33.

Goulas, E., M. Schubert, T. Kieselbach, L.A. Kleczkowski, P. Gardeström, and W.V. Schröder. 2006. The chloroplast lumen and stromal proteomes of Arabidopsis thaliana show differential sensitivity to short- and long-term exposure to low temperature. Plant J. 47:720-734.

Gupta, A.K. and N. Knaur. 2005. Sugar signalling and gene expression in relation to carbohydrate metabolism under abiotic stresses in plants. J. Biosci. 30:761-776.

He, Y., Z. Zhu, J. Yang, X. Ni, and B. Zhu. 2009. Grafting increases the salt tolerance of tomato by improvement of photosynthesis and enhancement of antioxidant enzymes activity. Environ. Exp. Bot. 66:270-278.

Ho, L.C. and P.J. White. 2005. A cellular hypothesis for the induction of blossom-end rot in tomato. Fruit Ann. Bot. 95:571-581.

Hodges, M.D., J.M. DeLong, C.F. Forney, and R.K. Prange. 1999. Improving the thiobarbituric acid-reactive-substances assay for estimating lipid peroxidation in plant tissues containing anthocyanin and other interfering compounds. Planta 207:604-611.

Kasper, T.C. and W.L. Bland. 1992. Soil temperature and root growth. Soil Sci. 154:290-299.

Kiegle, E., C.A. Moore, J. Haseloff, M.A. Tester, and M.R. Knight. 2000. Cell-type-specific calcium responses to drought, salt and cold in the arabidopsis root. Plant J. 23:267-278.

Knight, H., A.J. Trewavas, and M.R. Knight. 1996. Cold calcium signalling in arabidopsis involves two cellular pools and a change in calcium signature after acclimation. Plant Cell 8:489-503.

Kodama, H., G. Horiguchi, T. Nishiuchi, M. Nishimura, and K. Iba. 1995. Fatty acid desaturation during chilling acclimation is one of the factors involved in conferring low-temperature tolerance to young tobacco leaves. Plant Physiol. 107:1177-1185.

Korkmaz, A. and R.J. Dufault. 2002. Short-term cyclic cold temperature stress on water melon yield. HortScience 37:487-489.

Kratsch, H.A. and R.R. Wise. 2000. The ultrastructure of chilling stress. Plant Cell Environ. 23:337-350.

Lee, J.M. 1994. Cultivation of grafted vegetables. I. Current status, grafting methods, and benefits. HortScience 29:235-239.

Liu, B.H., L. Cheng, F.W. Ma, D. Liang, and Y.J. Zou. 2012. Influence of rootstock on drought response in young 'Gale Gala' apple (Malus domestica Borkh.) trees. J. Sci. Food Agr. 92:2421-2427.

Ma, Y., Y. Zhang, J. Lu, and H. Shao. 2009. Roles of plant soluble sugars and their responses to plant cold stress. Afr. J. Biotechnol. 8:2004-2010.

Macduff, J.H., A. Wild, M.J. Hopper, and M.S. Dhanoa. 1986. Effects of temperature on parameters of root growth relevant to nutrient uptake: Measurements on oilseed rape and barley grown in flowing nutrient solution. Plant Soil 94:321-332.

Mahajan, S. and N. Tuteja. 2005. Cold, salinity and drought stresses: An overview. Arch. Biochem. Biophys. 444:139-158.

Mitchell, D.E. and M.A. Madore. 1992. Patterns of assimilate production and translocation in muskmelon (Cucumis melo L.): II. Low temperature effects. Plant Physiol. 99:966-971.

Moore, S. and W.H. Stein. 1948. Photometric ninhydrin method for use in the chromatography of amino acids. J. Biol. Chem. 176:357-388.

Nishiyama, I. 1995. Damage due to extreme temperatures, p. 769-812. In: Matsuo, T., K. Kumazawa, R. Ishii, H. Ishihara, and H. Hirata (eds.). Science of the rice plant. Food Agr. Policy Res. Ctr., Tokyo, Japan.

Noctor, G. and C.H. Foyer. 1998. Ascorbate and glutathione: Keeping active oxygen under control. Annu. Rev. Plant Physiol. Plant Mol. Biol. 49:249-279. 
Ntatsi, G., D. Savvas, U. Druege, and D. Schwarz. 2013. Contribution of phytohormones in alleviating the impact of sub-optimal temperature stress on grafted tomato. Sci. Hort. 149:28-38.

Patterson, B.D., R. Paull, and R.M. Smillie. 1978. Chilling resistance in Lycopersicon hirsutum Humb. and Bonpl., a wild tomato with a wide altitudinal distribution. Aust. J. Plant Physiol. 5:609-617.

Paul, E.M.M., R.C. Hardwick, and P.F. Parker. 1984. Genotypic variation in the response to sub-optimal temperatures of growth in tomato (Lycopersicon esculentum Mill.). New Phytol. 98:221-230.

Rao, K.V.M. and T.V.S. Sresty. 2000. Antioxidant parameters in the seedlings of pigonpea [Cajanus cajan (L.) Millspaugh] in response to Zn and Ni stresses. Plant Sci. 157:113-128.

Rao, M.V., G. Paliyath, and D.P. Ormrod. 1996. Ultraviolet-B- and ozone-induced biochemical changes in antioxidant enzymes of Arabidopsis thaliana. Plant Physiol. 110:125-136.

Rick, C.M., J.W. Uhlig, and A.D. Jones. 1994. High alpha-tomatine content in ripe fruit of Andean Lycopersicon esculentum var. cerasiforme-Developmental and genetic aspects. Proc. Natl. Acad. Sci. USA 91:12877-12881.

Rook, F., F. Corke, R. Card, G. Munz, C. Smith, and M.W. Bevan. 2001. Impaired sucrose-induction mutants reveal the modulation of sugar-induced starch biosynthetic gene expression by abscisic acid signaling. Plant J. 26:421-433.

Rosa, M., C. Prado, G. Podazza, R. Interdonato, J.A. González, M. Hilal, and F.E. Prado. 2009a. Soluble sugars-Metabolism, sensing and abiotic stress: A complex network in the life of plants. Plant Signal. Behav. 4:388-393.

Rosa, M., M. Hilal, J.A. González, and F.E. Prado. 2009b. Lowtemperature effect on enzyme activities involved in sucrose-starch partitioning in salt-stressed and salt-acclimated cotyledons of quinoa (Chenopodium quinoa Wild.) seedlings. Plant Physiol. Biochem. 47:300-307.

Ruelland, E., M.N. Vaultier, A. Zachowski, and V. Hurry. 2009. Cold signaling and cold acclimation in plants. Adv. Bot. Res. 49:35-150.

Salinas, J. 2002. Molecular mechanisms of signal transduction in cold acclimation, p. 116-139. In: Scheel, D. and C. Wasternack (eds.). Plant signal transduction. Oxford Univ. Press, London, UK.

Schwarz, D. and H.-P. Kläring. 2001. Allometry to estimate leaf area of tomato. J. Plant Nutr. 24:1291-1309.

Schwarz, D., Y. Rouphael, G. Colla, and J.H. Venema. 2010. Grafting as a tool to improve tolerance of vegetables to abiotic stress. Thermal stress, water stress and organic pollutants. Sci. Hort. 127:162-171.

Siddiqui, K.S. and R. Cavicchioli. 2006. Cold-adapted enzymes. Annu. Rev. Biochem. 75:403-433.

Sirova, J., M. Sedlarova, J. Piterkova, L. Luhova, and M. Petrivalsky. 2011. The role of nitric oxide in the germination of plant seeds and pollen. Plant Sci. 181:560-572.

Sonnewald, U. 1992. Expression of E. coli inorganic pyrophosphatase in transgenic plants alters photoassimilate partitioning. Plant J. 2:571-581. Spooner, D.M., I.E. Peralta, and S. Knapp. 2005. Comparison of AFLPs with other markers for phylogenetic inference in wild tomatoes [Solanum L. section Lycopersicon (Mill.) Wettst.]. Taxonomy 54:43-61.

Strand, A., C.H. Foyer, P. Gustafsson, and V. Hurry. 2003. Increased expression of sucrose phosphate synthase in transgenic Arabidopsis thaliana results in improved photosynthetic performance and increased freezing tolerance al low temperatures. Plant Cell Environ. 26:523-535.

Sundar, D., K.V. Chaitanya, P.P. Jutur, and A.R. Reddy. 2004. Low temperature-induced changes in antioxidative metabolism in rubber-producing shrub, guayule (Parthenium argentatum Gray). Plant Growth Regulat. 44:175-181.

Tahtiharju, S., V. Sangwan, A.F. Monroy, R.S. Dhindsa, and M. Borg. 1997. The induction of kin genes in cold-acclimating Arabidopsis thaliana. Evidence of a role for calcium. Planta 203:442-447.

Theocharis, A., C. Clement, and E.A. Barka. 2012. Physiological and molecular changes in plants grown at low temperatures. Planta 235:1091-1105.

Tucker, D.E. and D.R. Ort. 2002. Low temperature induces expression of nitrate reductase in tomato that temporarily overrides circadian regulation of activity. Photosynth. Res. 72:285-293.

Tuteja, N. 2009. Cold, Salinity and drought stress, p. 137-159. In: Hirt, H. (ed.). Plant stress biology: From genomics to systems biology. Wiley VHC Verlag, Weinheim, Germany.

Van der Ploeg, A. and E. Heuvelink. 2005. Influence of sub-optimal temperature on tomato growth and yield: A review. J. Hort. Sci. Biotechnol. 80:652-659.

Venema, J.H., B.E. Dijk, J.M. Bax, P.R. Van Hasselt, and J.T.M. Elzenga. 2008. Grafting tomato (Solanum lycopersicum) onto the rootstock of a high-altitude accession of Solanum habroachites improves suboptimal-temperature tolerance. Environ. Exp. Bot. 63:359-367.

Venema, J.H., P. Linger, A.W. Van Heusden, P.R. Van Hasselt, and W. Brüggemann. 2005. The inheritance of chilling tolerance in tomato (Lycopersicon ssp.). Plant Biol. 7:118-130.

Venema, J.H., F. Posthumus, and P.R. Van Hasselt. 1999. Impact of suboptimal temperature on growth, photosynthesis, leaf pigments and carbohydrates of domestic and high-altitude wild Lycopersicon species. J. Plant Physiol. 155:711-718.

Walter, A., R. Feil, and U. Schurr. 2009. Environmental effects on spatial and temporal patterns of leaf and root growth. Annu. Rev. Plant Biol. 60:279-304.

Wilkinson, S., A.L. Clephan, and W.J. Davies. 2001. Rapid low temperature-induced stomatal closure occurs in cold-tolerant Commelina communis leaves but not in cold-sensitive tobacco leaves, via a mechanism that involves apoplastic calcium but not abscisic acid. Plant Physiol. 126:1566-1578.

Yadav, S.K. 2010. Cold stress tolerance mechanisms in plants. A review. Agron. Sustainainable Dev. 30:515-527.

Zhang, Y., Y. Zhang, Y. Zhou, and J. Yu. 2007. Adaptation of cucurbit species to changes in substrate temperature: Root growth, antioxidants, and peroxidation. J. Plant Biol. 50:527-532.

Zhang, Z.K., S.Q. Liu, S.Q. Hao, and S.H. Liu. 2010. Grafting increases the copper tolerance of cucumber seedlings by improvement of polyamine contents and enhancement of antioxidant enzymes activity. Agr. Sci. China 9:985-994.

Zhou, Y.H., L.F. Huang, Y. Zhang, K. Shi, J.Q. Yu, and S. Nogues. 2007. Chill-induced decrease in capacity of RuBP carboxylation and associated $\mathrm{H}_{2} \mathrm{O}_{2}$ accumulation in cucumber leaves are alleviated by grafting onto figleaf gourd. Ann. Bot. (Lond.) 100:839-845. 